Article

\title{
Synthesis and Characterization of Organic Dyes Containing Various Donors and Acceptors
}

Tzi-Yi Wu ${ }^{1,2}$, Ming-Hsiu Tsao ${ }^{1}$, Fu-Lin Chen ${ }^{1}$, Shyh-Gang Su ${ }^{1}$, Cheng-Wen Chang ${ }^{1}$, Hong-Paul Wang ${ }^{2,3}$, Yuan-Chung Lin ${ }^{4}$, Wen-Chung Ou-Yang ${ }^{5}$ and I-Wen Sun ${ }^{1,2, *}$

1 Department of Chemistry, National Cheng Kung University, Tainan, Taiwan

2 Sustainable Environment Research Center, National Cheng Kung University, Tainan 701, Taiwan

3 Department of Environmental Engineering, National Cheng Kung University, Tainan, Taiwan

4 Institute of Environmental Engineering, National Sun Yat-Sen University, Kaohsiung 804, Taiwan

5 Department of Chemical and Materials Engineering, National Kaohsiung University of Applied Sciences, Kaohsiung 80778, Taiwan

* Author to whom correspondence should be addressed; E-Mail: iwsun@mail.ncku.edu.tw; Tel.: +886-6-2757-575 ext: 65355 .

Received: 13 November 2009; in revised form: 23 December 2009 / Accepted: 17 January 2010 / Published: 22 January 2010

\begin{abstract}
New organic dyes comprising carbazole, iminodibenzyl, or phenothiazine moieties, respectively, as the electron donors, and cyanoacetic acid or acrylic acid moieties as the electron acceptors/anchoring groups were synthesized and characterized. The influence of heteroatoms on carbazole, iminodibenzyl and phenothiazine donors, and cyano-substitution on the acid acceptor is evidenced by spectral, electrochemical, photovoltaic experiments, and density functional theory calculations. The phenothiazine dyes show solar-energy-to-electricity conversion efficiency $(\eta)$ of $3.46-5.53 \%$, whereas carbazole and iminodibenzyl dyes show $\eta$ of $2.43 \%$ and $3.49 \%$, respectively.
\end{abstract}

Keywords: organic dyes; donor; absorption; electrochemistry; photovoltaic materials

\section{Introduction}

Donor-acceptor (D-A) organic molecules are among the most important conjugated organic materials, and have attracted much academic and technological research interest [1]. In these 
compounds the electron-donating and electron-accepting groups are connected through a $\pi$-conjugated linker. Tuning different donor moiety or acceptor moiety in a D-A molecule would modify its physical and chemical properties. The molecules with $\mathrm{D}-\pi-\mathrm{A}$ structures have attracted increasing attention since they can serve as electroactive and photoactive materials in molecular electronics, such as biochemical fluorescent technology [2], efficient nonlinear optical (NLO) materials [3], electrogenerated chemiluminescence [4], organic light-emitting diodes (OLEDs) [5], and solar cells [6].

So far, many organic donor- $\pi$-acceptor $(D-\pi-A)$ compounds have been studied experimentally and theoretically. Numerous species, including triarylamines [7], carbazoles [8], fluorenes [9], thiophenes, and oligothiophenes [10] have mostly been used as electron-donating moieties, whereas oxadiazoles [11], diarylborons [7], quinolines [12], quinoxalines [13], thienopyrazines [14], and benzothiadiazoles [15] are commonly used as electron-accepting moieties. In these compounds, the donor moiety facilitates hole injection and transport, whereas the acceptor moiety facilitates electron injection and transport [16]. Carbazole, $N, N$-dimethylbenzenamine, and phenothiazine are often adopted as donors as a result of their good thermal, electrochemical stability, and donating abilities [17]. The UV-vis absorption and photoluminescence (PL) of these compounds suggest significant intramolecular charge transfer (ICT) behavior and solvatochromism. The electrochemistry shows that the energy level of these compounds can be changed by altering the different donor moieties. Their photovoltaic properties were studied previously [6]. Recently, phenothiazine and its derivatives, outstanding heterocyclic compounds with high electron-donor ability, are attracting more research interest because of their potential applications in materials science, phenothiazines are also active in pharmacology as effective pharmacophores in tranquilizers, antituberculosis agents, antitumor agents, and bactericides [18].

Dye sensitizers, which function as light absorbers, are mainly divided into two kinds: one is metal complexes (ruthenium) and the other is metal-free organic dyes. Recently, more and more attention has been directed to the application of metal-free organic dyes in DSSCs because organic dyes do not require expensive ruthenium which is a limited resource, their relatively facile dye synthesis, and easy molecular tailoring. Pure organic dyes usually have much stronger light-harvesting ability than metal complexes because of their high extinction coefficients and very rich photophysical properties, it is promising to improve photocurrent to the theoretical maximum through molecular design of metal-free organic dyes. The organic dyes commonly consist of donor, linker, and acceptor groups (i.e., a D- $\pi$-A molecular structure). Their properties can be finely tuned by independently alternating or matching the different groups of D- $\pi$-A dyes. In the research for organic solar cells with high efficiency, the development of new materials offering optimized thermal and photochemical stabilities, optical and electrical properties. However, $\pi-\pi$ stacking of organic dye molecules usually occurs because of the strong intermolecular interaction. Although $\pi-\pi$ stacking is advantageous to light harvesting because of its broad feature in UV-vis absorption spectrum, $\pi$-stacked aggregate usually leads to inefficient electron injection and thus results in low power conversion efficiency [19]. Prohibition of $\pi$ - $\pi$ stacking with additive in the dye solution is a typical way to improve efficiency of organic dye-sensitized solar cells suffering from the $\pi-\pi$ stacking problem. Coadsorption of dye with additives [20] and structural modification of dye molecules [21] are proven to be effective to dissociate $\pi-\pi$ stacking or dye aggregation and thus to improve solar cell efficiency. 
In this work, new metal-free dyes with carbazole, iminodibenzyl, and phenothiazine sensitizers, respectively, are reported and their optical, electrochemical, photovoltaic properties, and structural relationships are investigated in detail. We synthesized four donor-acceptor $\pi$-conjugated dyes with a carboxyl group; the amine derivatives act as the electron donors while a 2-cyanoacrylic acid (or acrylic acid) moiety acts as the anchoring group for attachment on the metal oxide and as the electron acceptor. The two parts are connected by a $\pi$-conjugated methane unit. We investigate the electrondonating and electron-accepting nature, structural variations of the amine and acid unit, respectively, and study their electronic properties.

\section{Results and Discussion}

\subsection{Synthesis and Structure of Sensitizers}

As shown in Figure 1, D1-D3 are cyanoacetic acid-based dyes with carbazole, iminodibenzyl, and phenothiazine unit as the donor, respectively. D4 is an acrylic acid-based dye with a phenothiazine unit. The aldehydes 3, 6, 9 were prepared by a Vilsmeier reaction of $N$-ethylcarbazole, $\mathrm{N}$-ethyliminodibenzyl, and $\mathrm{N}$-ethylphenothiazine, respectively, with $\mathrm{POCl}_{3}$ in $\mathrm{DMF}$ [22]. The final reaction for D1-D4 was the condensation of the respective aldehyde with cyanoacetic acid (or malonic acid) by the Knoevenagel reaction in the presence of piperidine. The optimized structures of D1-D4 were studied to compare the structure differences between these photosensitizers (Figure 1). The dihedral angles $(\angle 1)$ of the D1 carbazole ring, the D2 iminodibenzyl ring, and the D3 phenothiazine ring are $108.7^{\circ}, 123.7^{\circ}$, and $122.1^{\circ}$, respectively, implying that the addition of a dimethylene bridge and sulfur units significantly increases the dihedral angle of nitrogen atoms. The dihedral angle between two phenyl units inside the carbazole unit $(\angle 4)$ of D1 is $106.4^{\circ}$; however, the dihedral angle between the phenyl unit and dimethylene bridge inside the iminodibenzyl unit $(\angle 4)$ of $\mathbf{D 2}$ is $126.1^{\circ}$. This can be attributed to the incorporation of a dimethylene bridge between two phenyl units increasing the steric hindrance, increasing the dihedral angles of $\angle 1$ and $\angle 4$. The dihedral angle $(\angle 8)$ of the D3 phenothiazine sulfur atom is $99.2^{\circ}$, which is smaller than that of the phenothiazine nitrogen atom $\left(\angle 1: 122.1^{\circ}\right)$. This may be attributed to the difference between nitrogen and sulfur atoms; nitrogen atom has a lone pair whereas sulfur atom has two lone pairs. For the cyanoacetic acid and acrylic acid-based dye, the dihedral angles $(\angle 9)$ of the D3 and D4 are $123.8^{\circ}$ and $121.6^{\circ}$, respectively, whereas dihedral angles $(\angle 10)$ of the $\mathbf{D 3}$ and $\mathbf{D 4}$ are $121.8^{\circ}$ and $125.1^{\circ}$, respectively implying that the incorporation of a electron-withdrawing cyano group decreases the dihedral angle $(\angle 10)$.

\subsection{Optical Properties}

Figure 2 shows the UV-Vis absorption and emission spectra for the four dyes in $\mathrm{CH}_{3} \mathrm{CN}$ and the $\lambda_{\max }$ are listed in Table 1, together with the UV-Vis spectra of the corresponding dyes adsorbed on $\mathrm{TiO}_{2}$ film. The absorption spectrum of $\mathbf{D 1}$ in $\mathrm{CH}_{3} \mathrm{CN}$ has three distinct absorption bands at around 288, 320 and $385 \mathrm{~nm}$, respectively. The absorption peaks at around $320 \mathrm{~nm}$ correspond to the $\pi \rightarrow \pi^{*}$ electron transition of the conjugated molecule; and the absorption peaks at around $385 \mathrm{~nm}$ can be assigned to an intramolecular charge transfer between the carbazole-based donor and the cyanoacetic acid [23], providing efficient charge-separation at the excited state. Under similar conditions, the D2 
sensitizer had absorption peaks at 258 and $368 \mathrm{~nm}$ that were blue-shifted relative to the peaks of D1, implying that the incorporation of dimethylene bridge destroys the conjugation between two phenyl groups. Compare the maximum absorption wavelength of D1-D3 in $\mathrm{CH}_{3} \mathrm{CN}$ solution. D3 (400 nm) shows a red shift relative to D1 $(385 \mathrm{~nm})$ and D2 $(368 \mathrm{~nm})$, which can be attributed to the extra electron-donating sulfur atom in D3. Such red-shifting in the absorption spectra implies a more effective utilizing of solar light. For the cyanoacetic acid and acrylic acid-based dyes (D3 and D4, respectively), when an electron acceptor $(-\mathrm{CN})$ was linked to the vinyl bridge, the maximum absorption was red-shifted from 381 to $400 \mathrm{~nm}$. The red shift of the maximum absorption peak arises from the fact that one more electron acceptor $(-\mathrm{CN})$ enhances the electron-withdrawing ability of electron acceptors and lowers the LUMO, thus reducing the gap between HOMO and LUMO.

Figure 2(b) shows the UV-Vis absorption spectra for the dye loaded $\mathrm{TiO}_{2}$ films with a bare $\mathrm{TiO}_{2}$ film as the reference. Upon dye adsorption onto the $\mathrm{TiO}_{2}$ surface, the maximum absorption respectively red-shifted by 23, 46, 26, and $31 \mathrm{~nm}$ for D1, D2, D3, and D4 as compared to the spectra in solution, implying that dyes adsorbed on the $\mathrm{TiO}_{2}$ surface had partial J-type aggregates. However, the stronger red shift of $\mathbf{D 2}(368 \mathrm{~nm} \rightarrow 414 \mathrm{~nm})$ compared to that of D1 $(385 \rightarrow 408 \mathrm{~nm})$ from the solution to $\mathrm{TiO}_{2}$ film may imply that the iminodibenzyl-containing sensitizer has a higher tendency to form surface binding with $\mathrm{TiO}_{2}$ than that of carbazole-containing sensitizer, as chelating to metal cation, it may enhance the intramolecular electron transfer (ICT), leading to spectrum shift. Under similar conditions, the D3 and D4 sensitizers showed a slight red shift $(400 \rightarrow 426 \mathrm{~nm}$ and $381 \rightarrow 412 \mathrm{~nm}$, respectivity) after being adsorbed on the $\mathrm{TiO}_{2}$ surface.

Figure 1. Optimized geometric parameters (dihedral angle) of (a) D1: $\angle 1=108.7^{\circ}, \angle 2=$ $125.4^{\circ}, \angle 3=125.9^{\circ}, \angle 4=106.4^{\circ}, \angle 5=134.0^{\circ}, \angle 6=106.6^{\circ}, \angle 7=134.0^{\circ}$; (b) D2: $\angle 1=$ $123.7^{\circ}, \angle 2=118.9^{\circ}, \angle 3=117.3^{\circ}, \angle 4=126.1^{\circ}, \angle 5=115.7^{\circ}, \angle 6=119.4^{\circ}, \angle 7=121.5^{\circ}$, $\angle 8=116.2^{\circ}, \angle 9=111.1^{\circ}$; (c) D3: $\angle 1=122.1^{\circ}, \angle 2=118.3^{\circ}, \angle 3=118.8^{\circ}, \angle 4=120.6^{\circ}$, $\angle 5=118.3^{\circ}, \angle 6=120.4^{\circ}, \angle 7=118.5^{\circ}, \angle 8=99.2^{\circ}, \angle 9=123.8^{\circ}, \angle 10=121.8^{\circ}$; (d) D4: $\angle 1=121.8^{\circ}, \angle 2=118.5^{\circ}, \angle 3=118.7^{\circ}, \angle 4=120.5^{\circ}, \angle 5=118.3^{\circ}, \angle 6=120.4^{\circ}, \angle 7=$ $118.4^{\circ}, \angle 8=99.2^{\circ}, \angle 9=121.6^{\circ}, \angle 10=125.1^{\circ}$.

(a)

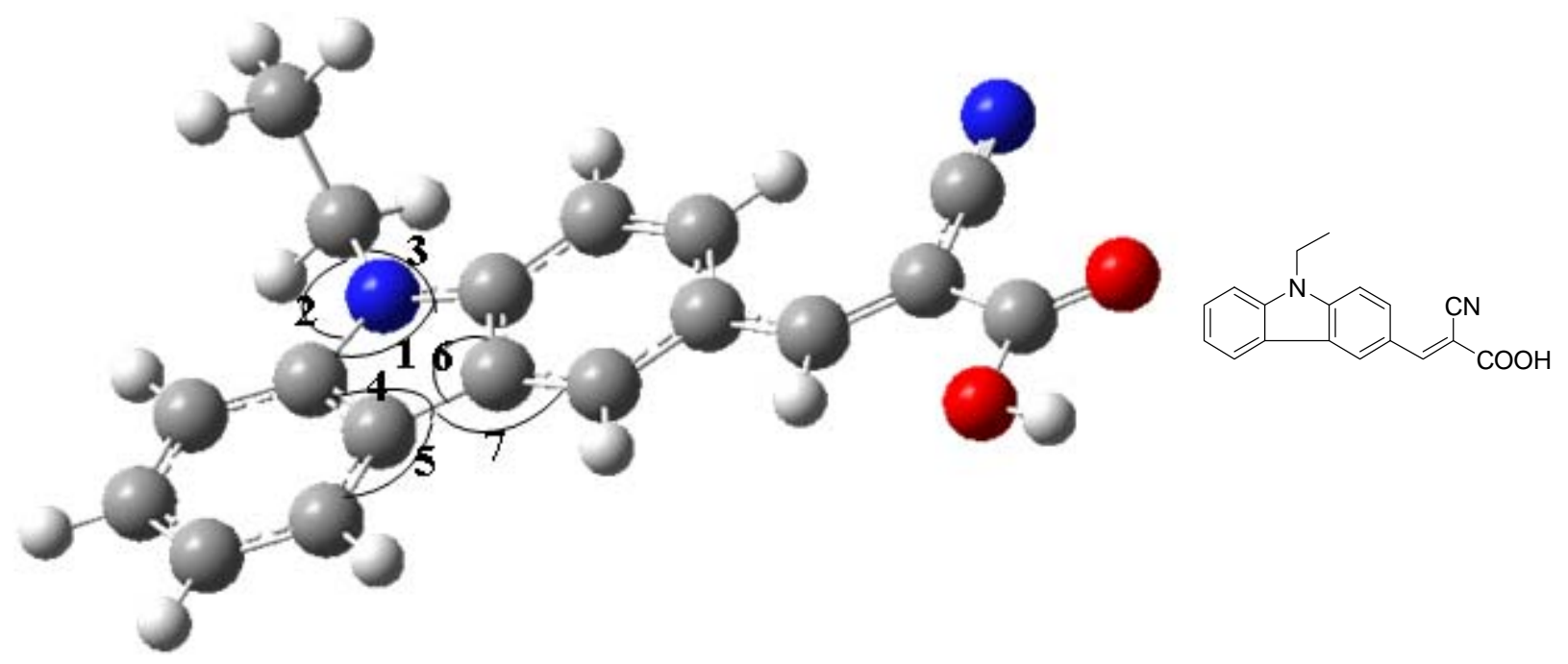


Figure 1. Cont.

(b)

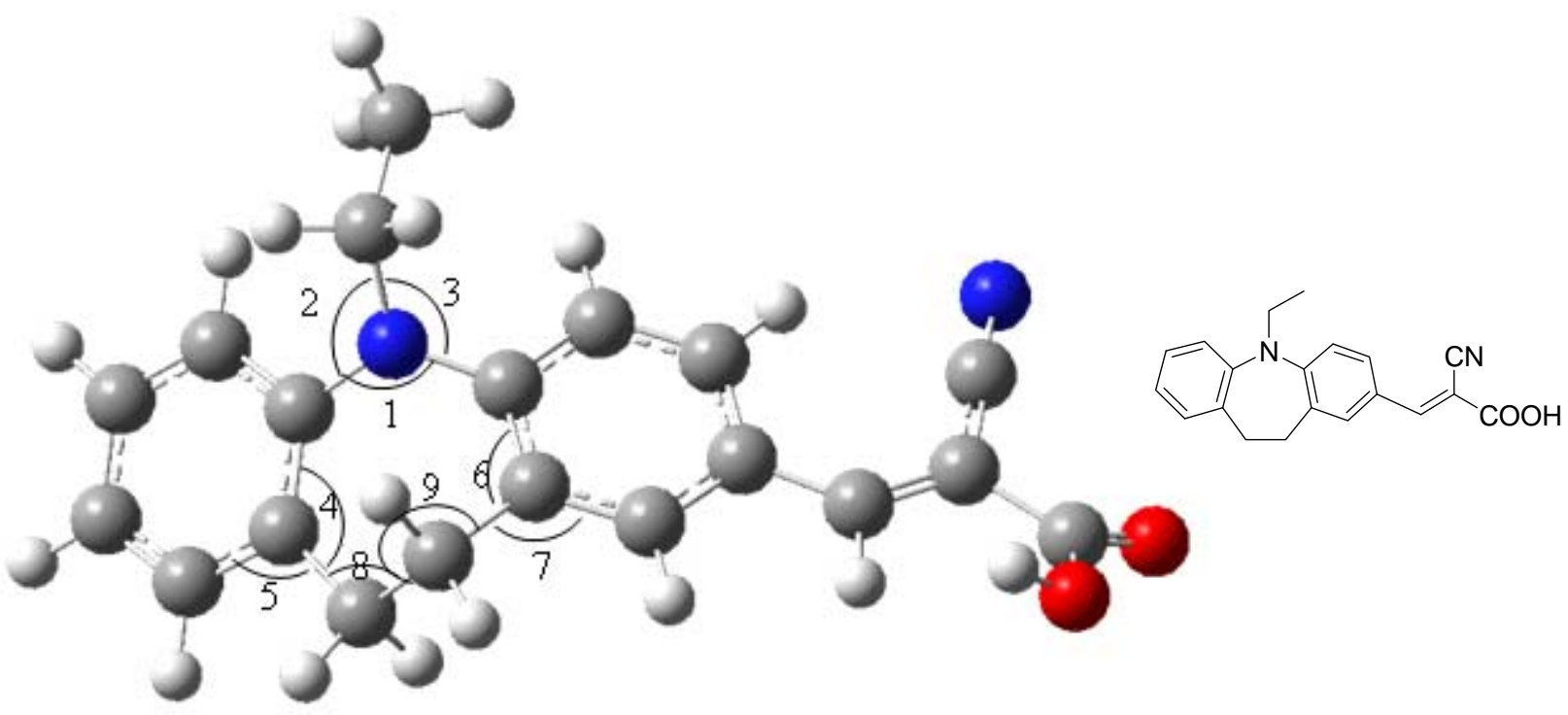

(c)

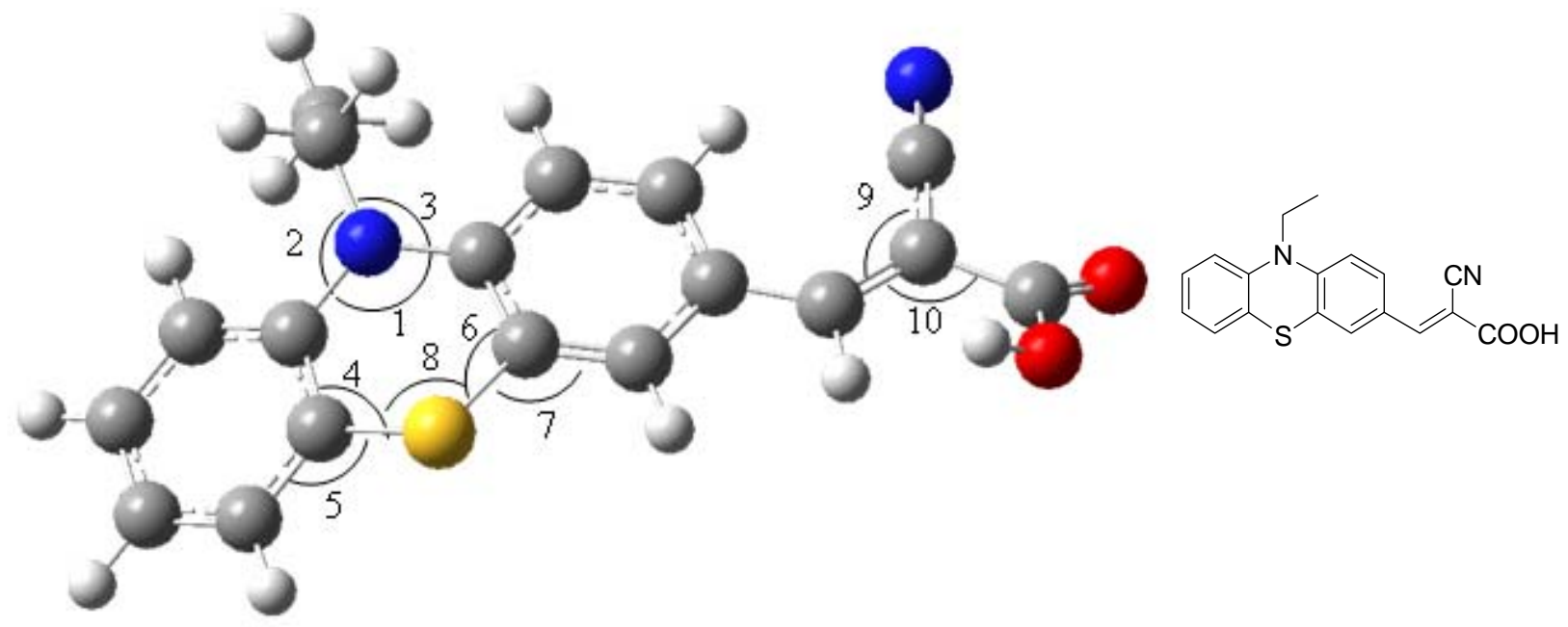

(d)

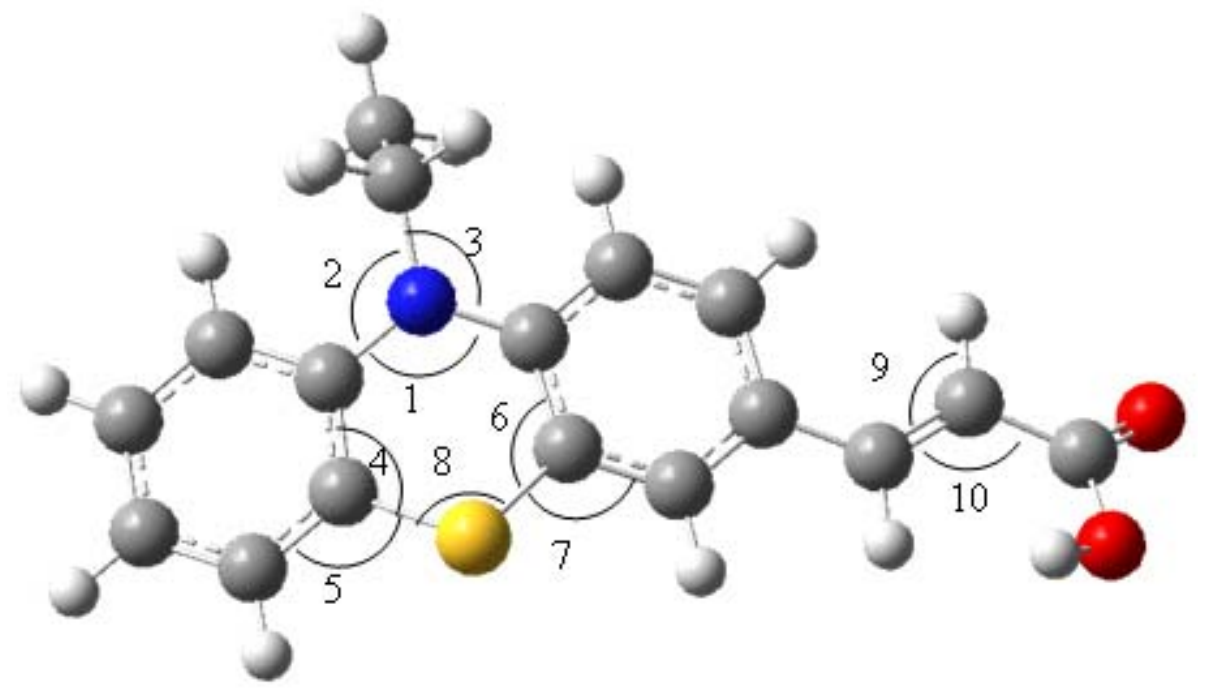<smiles>CCN1c2ccccc2Sc2cc(/C=C/C(=O)O)ccc21</smiles> 
Figure 2. Absorption and emission spectra of D1-D4 in $\mathrm{CH}_{3} \mathrm{CN}$ and absorption spectra of D1-D4 adsorbed on $\mathrm{TiO}_{2}$ film.
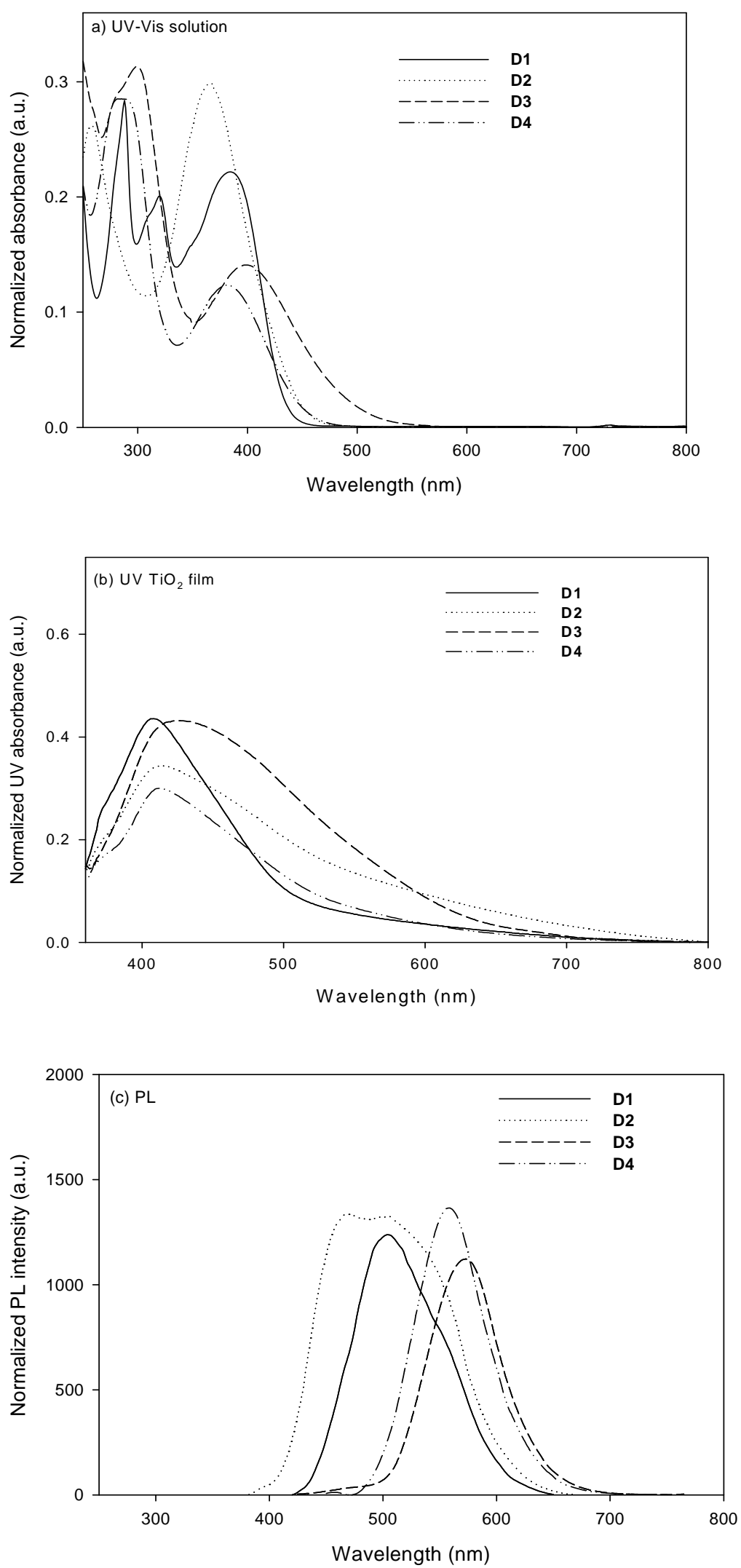
The absorption spectra of D1-D4 on the $\mathrm{TiO}_{2}$ electrode are broader than those in $\mathrm{CH}_{3} \mathrm{CN}$. The broadening of the absorption spectra is due to an interaction between the dyes and $\mathrm{TiO}_{2}$ [24]. The absorption redshift of $\mathbf{D 3}$ relative to D2 is due to its stronger intramolecular charge transfer because phenothiazine is a stronger electron-donating ring than iminodibenzyl. The molar extinction coefficients of D1, D2, D3, and D4 in $\mathrm{CH}_{3} \mathrm{CN}$ solution are 22,975 $\mathrm{M}^{-1} \mathrm{~cm}^{-1}$ (at $385 \mathrm{~nm}$ ), 29,846 $\mathrm{M}^{-1} \mathrm{~cm}^{-1}$ (at $368 \mathrm{~nm}$ ), 14,096 $\mathrm{M}^{-1} \mathrm{~cm}^{-1}$ (at $400 \mathrm{~nm}$ ), and 12,639 $\mathrm{M}^{-1} \mathrm{~cm}^{-1}$ (at $381 \mathrm{~nm}$ ), respectively; they are comparable or larger than that of $\mathbf{N 3}$ (cis-bis(isothiocyanato)bis(2,2'-bipyridyl-4,4'-dicarboxylato)ruthenium(II)) $\left(14,200 \mathrm{M}^{-1} \mathrm{~cm}^{-1}\right)$ [25], indicating that the novel dyes have good light harvesting ability.

As shown in Figure 2 (c), the PL maxima of D1 are located at $504 \mathrm{~nm}$ in $\mathrm{CH}_{3} \mathrm{CN}$, whereas those of D2 shifted to 470 and $506 \mathrm{~nm}$, and those of D3 and D4 shifted to 573 and $558 \mathrm{~nm}$, respectively. D3 and D4 exhibited a relatively large Stokes shift (173 and $177 \mathrm{~nm}$, respectively), which could be attributed to the geometrically relaxed structure of the phenothiazine center upon excitation [26].

Table 1. Absorption and emission properties of dyes.

\begin{tabular}{cccccc}
\hline Dye & \multicolumn{3}{c}{ Absorption } & Emission & Stokes shift $^{\mathbf{a}}$ \\
\hline & $\lambda_{\text {abs }}{ }^{\mathrm{b}}(\mathrm{nm})$ & $\varepsilon\left(\mathrm{M}^{-1} \mathrm{~cm}^{-1}\right)\left(\mathrm{at} \lambda_{\mathrm{abs}}\right)$ & $\lambda_{\text {abs }}{ }^{\mathrm{b}}(\mathrm{nm})\left(\mathrm{on} \mathrm{TiO}_{2}\right)$ & $\lambda_{\mathrm{em}}{ }^{\mathrm{b}}(\mathrm{nm})$ & $(\mathrm{nm})$ \\
\hline D1 $^{\mathrm{b}}$ & $288,320,385$ & $22975(385 \mathrm{~nm})$ & 408 & 504 & 119 \\
D2 & 258,368 & $29846(368 \mathrm{~nm})$ & 414 & 470,506 & 138 \\
D3 & 299,400 & $14096(400 \mathrm{~nm})$ & 426 & 573 & 173 \\
D4 & 285,381 & $12639(381 \mathrm{~nm})$ & 412 & 558 & 177 \\
\hline
\end{tabular}

${ }^{\mathrm{a}}$ Stokes shift $=\mathrm{PL}_{\text {(soluion) }}(\mathrm{nm})-\mathrm{UV}_{\text {(solution) }}(\mathrm{nm}) .{ }^{\mathrm{b}}$ Absorption and emission spectra were measured in $\mathrm{CH}_{3} \mathrm{CN}$ solution.

\subsection{Electrochemical Properties}

To judge the possibilities of electron transfer from the excited dye molecule to the conductive band of $\mathrm{TiO}_{2}$ and the dye regeneration, redox potentials of D1-D4 in acetonitrile were obtained using cyclic voltammetry (as shown in Figure 3). The electrochemical data are listed in Table 2. The excited-state oxidation potentials were obtained from the first oxidation potential $\mathrm{E}_{\mathrm{ox}}(v s$. NHE) measured by cyclic voltammetry, the ferrocenium/ferrocene $\left(\mathrm{Fc} / \mathrm{Fc}^{+}\right)$redox couple was used as an internal potential reference. The excited-state oxidation potential $E\left(\mathrm{~S}^{+} / \mathrm{S}^{*}\right)$ was calculated using Equation 1 [27].

$$
E\left(\mathrm{~S}^{+} / \mathrm{S}^{*}\right)=E\left(\mathrm{~S}^{+} / \mathrm{S}\right)-E_{0-0}
$$

where $E\left(\mathrm{~S}^{+} / \mathrm{S}\right)$ is the ground state oxidation potential of D1-D4 and $E_{0-0}$ is the zeroth-zeroth transition value obtained by the intersection of the normalized lowest energy absorption peak and highest energy fluorescence peak. All $E_{0-0}$ values in our experiment were obtained by the absorption and fluorescence spectra measured in acetonitrile which was also used in the preparation of sandwich cell.

When D1 was swept in the anodic direction, there was an oxidation peak at $1.25 \mathrm{~V}$, which corresponded to the first oxidation steps (formation of the radical cation). However, there was no reduction peak, indicating that the electrochemical behavior in the anodic direction was irreversible. For D2, the oxidation was also irreversible, with peaks appearing at 1.00 and $1.42 \mathrm{~V}$, which corresponded to the first and second oxidation steps (forming the radical cation and dication), 
respectively. They are higher than those of D1, which could be attributed to the relatively higher electron density on the nitrogen atoms of D2, which allowed it to be more easily oxidized than a carbazole derivative.

Figure 3. Cyclic voltamogram of D1-D4 in acetonitrile.

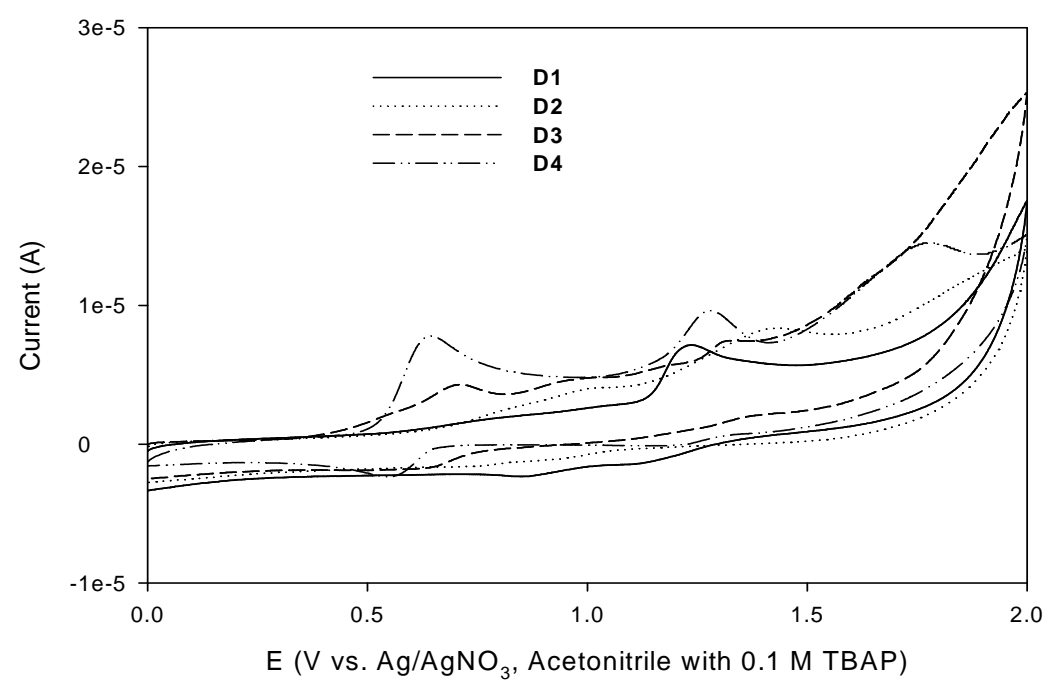

It is evident that the iminodibenzyl unit enhanced the hole transporting ability of the photosensitizer more than that of the carbazole unit. The oxidation of D3 was quasi-reversible, with peaks located at 0.72 and $1.35 \mathrm{~V}$. Both the first and second oxidation potentials are smaller than those of D2, indicating that the phenothiazine units are much more effective in lowering the ionization potential than iminodibenzyl units. The oxidation of D4 was also quasi-reversible, with three peaks located at 0.63 , 1.29 , and $1.76 \mathrm{~V}$, comparison of these results with previously reported redox properties of phenothiazine-containing oligomers [28] allow assignment of the three waves to the phenothiazine radical cation, dication, and trication, respectively. The irreversibility of the second and third oxidation waves likely stems from the highly reactive nature of the dication and trication [28]. Both the first and second oxidation potentials of $\mathbf{D 3}(0.72$ and $1.35 \mathrm{~V})$ are larger than those of D4 (0.63 and $1.29 \mathrm{~V})$, indicating that the incorporation of electron-withdrawing cyano groups at the vinyl bridge enhanced electron affinity significantly. Moreover, introducing a phenothiazine group into the photosensitizer framework (D3 and D4) resulted in a largely negative shift of the HOMO level, to 0.52-0.54 V vs. NHE. The HOMO levels of D1 and D2 (1.14 and 0.77 V vs. NHE, respectively) are more positive than that of D3, indicating more efficient dye regeneration for D1 and D2. For the cyanoacetic acid and acrylic acid-based dyes (D3 and D4, respectively), the incorporation of electron-withdrawing cyano groups at the vinyl bridge increases the LUMO level $[-2.04 \mathrm{~V}(\mathbf{D 4}) \rightarrow-1.92 \mathrm{~V}(\mathbf{D 3})]$. The LUMO level of D2 (-2.14 V vs. NHE) is more negative than those of D1, D3, and D4 $(-1.70,-1.92 \mathrm{~V}$, and -2.04 vs. NHE, respectively), indicating that $\mathbf{D 2}$ dye has more efficient electron injection. 
Table 2. Electrochemical properties and band gaps of D1-D3 dyes.

\begin{tabular}{|c|c|c|c|c|c|c|c|}
\hline Dye & $\mathbf{E}_{\mathrm{pa}}$ & $\mathbf{E}_{\text {onset(ox) }}$ & $\begin{array}{c}\mathbf{E}_{\text {onset(ox) }} v s . \\
\mathbf{E}_{\mathrm{FOC}}{ }^{\mathrm{a}}(\mathrm{V})\end{array}$ & $\begin{array}{c}\mathbf{E}\left(\mathbf{S}^{+} / \mathbf{S}^{*}\right)^{\mathbf{b}, \mathbf{d}}(\mathbf{V}) \\
\text { vs. NHE }\end{array}$ & $\begin{array}{c}E_{0-0}{ }^{c} \\
(V)\end{array}$ & LUMO & $E_{\text {gap }}(V)^{\mathrm{e}}$ \\
\hline D1 & 1.25 & 1.11 & 0.85 & 1.14 & 2.84 & -1.70 & 1.2 \\
\hline D2 & $1.00,1.42$ & 0.74 & 0.48 & 0.77 & 2.91 & -2.14 & 1.64 \\
\hline D3 & $0.72,1.35$ & 0.49 & 0.23 & 0.52 & 2.44 & -1.92 & 1.42 \\
\hline D4 & $\begin{array}{c}0.63,1.29 \\
1.76\end{array}$ & 0.51 & 0.25 & 0.54 & 2.58 & -2.04 & 1.54 \\
\hline
\end{tabular}

${ }^{\mathrm{a}} \overline{\mathrm{E}_{\mathrm{FOC}}=0.26 \mathrm{~V} \text { vs. } \mathrm{Ag} / \mathrm{Ag}^{+} \cdot{ }^{\mathrm{b}} \text { The ground-state oxidation potentials } \mathrm{E}\left(\mathrm{S}^{+} / \mathrm{S}\right) \text { were measured on } 0.1 \mathrm{M}}$ tetrabutylammonium perchlorate in acetonitrile using a glassy carbon working electrode, a Pt counter electrode, and a $\mathrm{Ag} / \mathrm{Ag}^{+}$reference electrode. ${ }^{\mathrm{c}}$ The $\mathrm{E}_{0-0}$ value was estimated from the cross-section of absorption and emission spectra. ${ }^{d}$ The excited-state oxidation potential $\mathrm{E}\left(\mathrm{S}^{+} / \mathrm{S}^{*}\right)$ was calculated from $\mathrm{E}\left(\mathrm{S}^{+} / \mathrm{S}\right)-\mathrm{E}_{0-0 .}{ }^{\mathrm{e}} \mathrm{E}_{\text {gap }}$ is the energy gap between $\mathrm{E}\left(\mathrm{S}^{+} / \mathrm{S}^{*}\right)$ of the dye and the conduction band level of $\mathrm{TiO}_{2}(-0.5 \mathrm{~V} v s . \mathrm{NHE})$

Figure 4 shows the schematic energy diagram of these dye-sensitized $\mathrm{TiO}_{2}$ electrodes. All the excited state oxidation potentials (LUMO) of D1 $(-1.70 \mathrm{~V})$, D2 $(-2.14 \mathrm{~V}), \mathbf{D 3}(-1.92 \mathrm{~V})$, and D4 $(-2.04 \mathrm{~V})$ are more negative than the conduction band edge of $\mathrm{TiO}_{2}[-0.5 \mathrm{~V}$ (vs. NHE)] [29]. Provided that an energy gap (between dye $\mathrm{LUMO}$ and $\mathrm{TiO}_{2} \mathrm{CB}$ ) of $0.2 \mathrm{eV}$ is necessary for efficient electron injection [30], the driving force is sufficient for efficient charge injection. Thus, the electron injection process from the excited dye molecule to the $\mathrm{TiO}_{2}$ conduction band and the subsequent dye regeneration are energetically permitted. Figure 4 also indicates that the energy levels of the ground state $(\mathrm{HOMO})$ of D1 $(1.14 \mathrm{~V}), \mathbf{D} 2(0.77 \mathrm{~V}), \mathbf{D 3}(0.52 \mathrm{~V})$, and D4 $(0.54 \mathrm{~V})$ are sufficiently more positive than the $\mathrm{I}_{3}^{-} / \mathrm{I}^{-}$redox potential $(0.42 \mathrm{~V}$ (vs. NHE) [29], indicating that the oxidized dye formed after electron injection into the conduction band of $\mathrm{TiO}_{2}$ could accept electrons from $\mathrm{I}^{-}$ions in the electrolyte thermodynamically. Such electronic structures thus ensure a favorable exothermic flow of charges throughout the photo-electronic conversion.

\subsection{Molecular Orbital Calculations}

The geometrical and electronic properties of D1-D4 were studied with density functional theory (DFT) using the Gaussian 03 program package [31], as shown in Figure 5. The calculations were done on a B3LYP/6-31G(d) level for geometry optimizations in the ground state. B3LYP is a hybrid function modified from the three-parameter exchange-correlation functional of Becke [32], while the gradient-corrected exchange and correlation functions are calculated according to Becke [33] and Lee et al. [34]. The frontier MOs of D2-D4 reveal that HOMO-LUMO excitation moves the electron density distribution from the iminodibenzyl, phenothiazine moiety to the cyanoacrylic acid (or acrylic acid) moiety; however, the frontier MOs of D1 reveal that the electrons at the ground state (HOMO) are homogeneously distributed in both the electron donor group and the methylene bridge of the cyanoacrylic acid. Comparing the frontier MOs of D2 and D3 (or D4) at the ground state (HOMO), the electrons of $\mathbf{D 2}$ are dominantly distributed in the benzene ring and the nitrogen atom; however, there are few electrons in the dimethylene bridge of the iminodibenzyl unit, the electrons of D3 (or D4) are homogeneously distributed in the phenothiazine unit. The LUMO electron density geometry 
distributions of D1-D4 are located over the cyanoacrylic (or acrylic) group through the right phenyl group and the nitrogen atom of carbazole, iminodibenzyl and phenothiazine units, respectively. However, the LUMO + 1 of D1-D4 is centered on the phenyl group of carbazole, iminodibenzyl, and phenothiazine units. At the excited state (LUMO) with light illumination for D1-D4 dyes, intramolecular charge transfer occurs, resulting in electron movement from the donor groups to the acceptor groups (cyanoacrylic and acrylic groups). Furthermore, the location of the LUMO at the side of the $\mathrm{TiO}_{2}$ surface and the HOMO at the opposite end of the molecule makes the electron injection into the semiconductor easier and prevents back regeneration of the dye with injected electrons.

Figure 4. Schematic energy level diagram for a DSSC based on dyes.

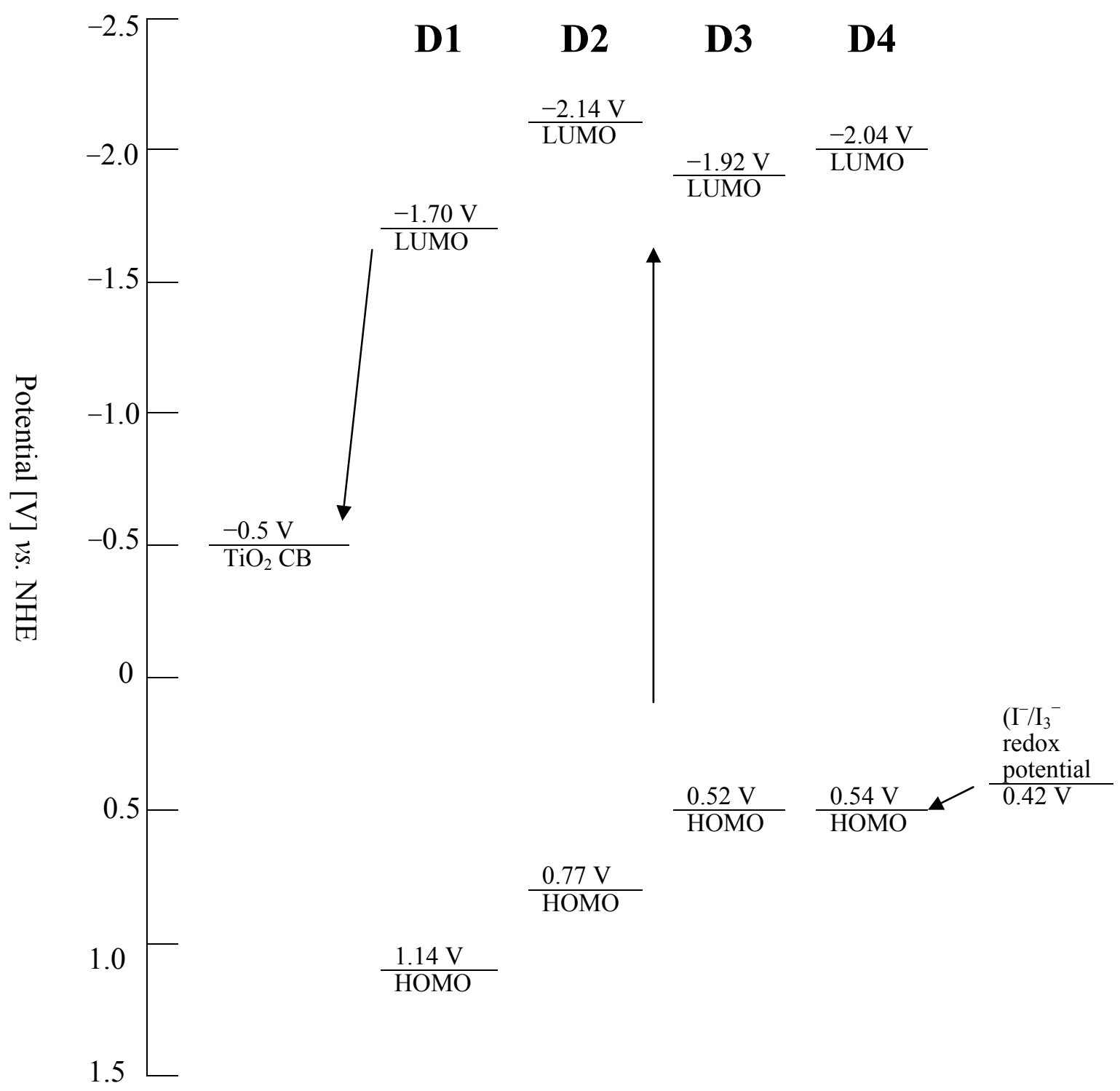


Figure 5. Computed isodensity surfaces of HOMO and LUMO orbitals of D1-D4.

D1
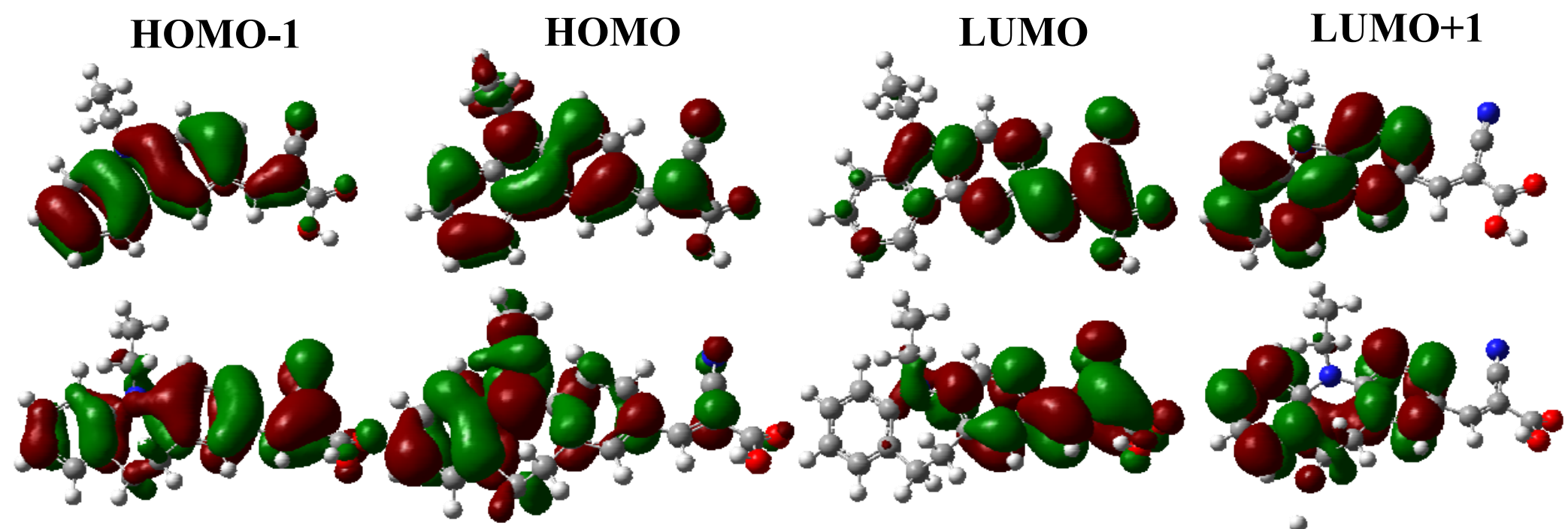

D2

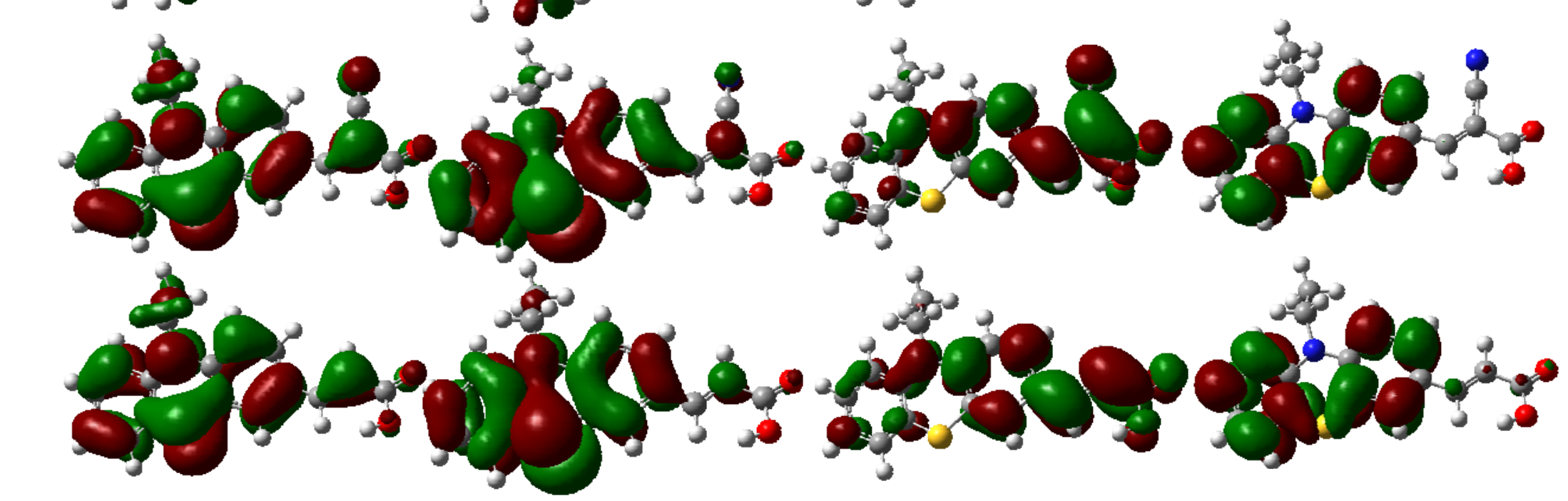

D3 
Table 3. Comparison of calculated TD-DFT excitation energies (eV, nm), oscillator strengths (f), assignment of molecular orbital contributions and character, and experimental absorption band maxima of dyes.

\begin{tabular}{|c|c|c|c|c|c|c|c|}
\hline Dye & $\begin{array}{l}\text { Excited } \\
\text { State }\end{array}$ & $\mathbf{f}$ & Est (eV) & Est(nm) & $\operatorname{Exp}(e V)$ & $\operatorname{Exp}(\mathbf{n m})$ & Composition \\
\hline \multirow{3}{*}{ D1 } & 1 & 0.5501 & 3.09 & 400.71 & 3.22 & 385 & $0.17823 \chi($ HOMO-1 -> LUMO $)+0.63923 \chi($ HOMO -> LUMO $)$ \\
\hline & 2 & 0.1848 & 4.05 & 305.92 & 3.88 & 320 & $\begin{array}{l}-0.23908 \chi(\mathrm{HOMO}-2->\text { LUMO })-0.10901 \chi(\mathrm{HOMO}-1->\mathrm{LUMO}) \\
-0.13026 \chi(\mathrm{HOMO}-1->\mathrm{LUMO}+2)+0.60862 \chi(\mathrm{HOMO}->\mathrm{LUMO}+1)\end{array}$ \\
\hline & 3 & 0.4164 & 4.62 & 268.62 & 4.31 & 288 & $\begin{array}{l}0.15891(\mathrm{HOMO}-4->\mathrm{LUMO})+0.11418 \chi(\mathrm{HOMO}-2->\mathrm{LUMO}+1) \\
+0.59488 \chi(\mathrm{HOMO}-1->\mathrm{LUMO}+1)+0.21489 \chi(\mathrm{HOMO}->\mathrm{LUMO}+2)\end{array}$ \\
\hline \multirow{3}{*}{ D2 } & 1 & 0.2724 & 3.80 & 325.88 & 3.37 & 368 & $0.33984 \chi($ HOMO-3 -> LUMO $)+0.56799 \chi($ HOMO-2 -> LUMO $)$ \\
\hline & 2 & 0.0519 & 3.61 & 343.67 & & & $0.69422 \chi($ HOMO-1 -> LUMO) \\
\hline & 3 & 0.0788 & 4.69 & 264.17 & 4.81 & 258 & $0.25285 \chi($ HOMO-5 -> LUMO $)+0.62718 \chi($ HOMO-4-> LUMO $)$ \\
\hline \multirow{3}{*}{ D3 } & 1 & 0.325 & 3.46 & 358.48 & 3.10 & 400 & $0.66021 \chi(\mathrm{HOMO}-1$-> LUMO $)+0.17024 \chi(\mathrm{HOMO}->$ LUMO +1$)$ \\
\hline & 2 & 0.421 & 4.16 & 298.32 & 4.15 & 299 & $0.62223 \chi(\mathrm{HOMO}-2->$ LUMO $)+0.23525(\mathrm{HOMO}->\mathrm{LUMO}+3)$ \\
\hline & 3 & 0.1902 & 3.85 & 321.92 & & & $\begin{array}{l}-0.14214 \chi(\mathrm{HOMO}-1->\text { LUMO })+0.64038 \chi(\mathrm{HOMO}->\mathrm{LUMO}+1) \\
-0.13726 \chi(\mathrm{HOMO}->\text { LUMO }+2)\end{array}$ \\
\hline \multirow{3}{*}{ D4 } & 1 & 0.3013 & 2.84 & 435.84 & 3.25 & 381 & $0.65955 \chi(\mathrm{HOMO}$-> LUMO $)$ \\
\hline & 2 & 0.3325 & 4.34 & 285.39 & 4.35 & 285 & $\begin{array}{l}-0.18518 \chi(\text { HOMO- }->\text { LUMO })-0.17372 \chi(\text { HOMO- } 1 \text {-> LUMO }) \\
+0.61772 \chi(\text { HOMO }->\text { LUMO }+3)\end{array}$ \\
\hline & 3 & 0.1149 & 4.60 & 269.81 & & & $\begin{array}{l}-0.10745 \chi(\text { HOMO- } 5 \text {-> LUMO })+0.36767 \chi(\text { HOMO }-4 \text {-> LUMO })+ \\
0.51568 \chi(\text { HOMO- }->\text { LUMO })+0.12964 \chi(\text { HOMO }->\text { LUMO }+3)\end{array}$ \\
\hline
\end{tabular}


The vertical excitations were calculated by time dependent density functional theory (TDDFT) with B3LYP/6-31 + G(d) in vacuo and in $\mathrm{CH}_{3} \mathrm{CN}$ solution. It was found that the inclusion of solvation effects does not lead to a qualitative change in the electronic structure, even though smaller HOMO-LUMO gaps were calculated in $\mathrm{CH}_{3} \mathrm{CN}$ as compared to the gas phase. The origins of these electronic absorptions were found by calculating the singlet electronic transitions with the TDDFT method in Gaussian 03W program suite. Calculations show that these visible bands are mainly attributed to the electronic transition from the highest occupied molecular orbitals (HOMOs) to the lowest unoccupied molecular orbitals (LUMOs). Table 3 shows the calculated absorption maxima in the visible region, their oscillator strengths, and their compositions for D1-D4. To analyze the photophysical properties of these dyes, we performed TD-DFT calculations of the lowest 10 singletsinglet excitations of dyes in $\mathrm{CH}_{3} \mathrm{CN}$ solutions. The three transitions of D1-D4 with oscillator strengths $(f)$ above 0.05 are summarized in Table 3. Compared with the experimental data, the considerable blue-shift of the absorption maximum from the calculations is related to the selfinteraction error in TD-DFT arising from the electron transfer in the extended charge-transfer state [35]. The calculated absorption maxima for the excited states seem in good agreement with the measured values, supporting the band assignments in the UV solution plot.

\subsection{Photovoltaic Performance}

DSSCs were prepared and compared to investigate the relationships between the sensitizing behavior of D1-D4 dye molecules and their structures. The dye-sensitized solar cells were constructed by using these dyes as a sensitizer for nanocrystalline anatase $\mathrm{TiO}_{2}$.

The incident photon-to-current conversion efficiency (IPCE) of a DSSC was calculated by normalizing the photocurrent densities for incident light energy and intensity according to the Equation 2 [36]:

$$
\operatorname{IPCE}(\lambda)=\frac{1240(\mathrm{eV} \cdot \mathrm{nm})}{\lambda(\mathrm{nm})} \frac{J_{s c}\left(\mathrm{~mA} \cdot \mathrm{cm}^{-2}\right)}{\phi\left(\mathrm{mW} \cdot \mathrm{cm}^{-2}\right)}
$$

where $J_{\text {sc }}$ is the short-circuit photocurrent generated by monochromatic light, $\lambda$ is the wavelength of incident monochromatic light, and $\phi$ is the power of the incident radiation per unit area.

Figure 6 shows action spectra of monochromatic incident-to current conversion efficiencies (IPCEs) for DSSCs using D1-D4. The IPCEs of D1-D4 are more than 50\% in the spectral range from 400 to $430 \mathrm{~nm}$. D3 reaches its maximum of $82 \%$ at $430 \mathrm{~nm}$, whereas D1, D2, and D4 reach their maximums of $60-66 \%$ at $410-420 \mathrm{~nm}$. When reflection and absorption losses of the FTO glass substrate are considered, the net photon-to-electron conversion efficiencies of the D1-D4 would almost exceed $85 \%$ in their spectral ranges. The decrease of the IPCE above $600 \mathrm{~nm}$ in the longwavelength region is attributed to the decrease of light harvesting for these dyes. The lower photocurrent response of D1, D2, and D4 sensitized devices is ascribed to the blue shifted dyes with a higher energy band-gap compared to that of the $\mathbf{D 3}$ dye.

A typical photocurrent-photovoltage $(I-V)$ curve for cells based on D1-D4 is shown in Figure 7. The detailed photovoltaic parameters are summarized in Table 4. The solar-energy-to-electricity conversion efficiency $(\eta)$ of the DSSCs is calculated from short-circuit current $\left(J_{\mathrm{sc}}\right)$, the open-circuit 
photovoltage $\left(V_{\mathrm{oc}}\right)$, the fill factor $(\mathrm{FF})$, and the intensity of the incident light $\left(P_{\text {in }}\right)$ according to the following Equation [36]:

$$
\eta=\frac{\left[J_{s c}\left(\mathrm{~mA} \cdot \mathrm{cm}^{-2}\right)\right]\left[V_{o c}(\mathrm{~V})\right][\mathrm{FF}]}{P_{i n}\left(\mathrm{~mW} \cdot \mathrm{cm}^{-2}\right)}
$$

Table 4. Photovoltaic performance of DSSCs based on D1-D4 dyes.

\begin{tabular}{ccccc}
\hline Dye & $\mathrm{V}_{\mathrm{oc}}(\mathrm{V})$ & $\mathrm{J}_{\mathrm{sc}}\left(\mathrm{mA} \mathrm{cm}^{-2}\right)$ & Fill factor (ff) & $\eta(\%)$ \\
\hline D1 & 0.595 & 5.76 & 0.71 & 2.43 \\
D2 & 0.620 & 8.28 & 0.68 & 3.49 \\
D3 & 0.669 & 13.35 & 0.62 & 5.53 \\
D4 & 0.628 & 8.09 & 0.68 & 3.46 \\
\hline
\end{tabular}

${ }^{\text {a }}$ Measured under irradiation of AM $1.5 \mathrm{G}$ simulated solar light $\left(100 \mathrm{~mW} \mathrm{~cm}^{-2}\right)$ at room temperature, $10 \mu \mathrm{m}$ film thickness, $0.25 \mathrm{~cm}^{2}$ working area. ${ }^{\mathrm{b}}$ The concentration of dye is $2 \times 10^{-4} \mathrm{M}$ in $\mathrm{CH}_{3} \mathrm{CN}$ and $0.6 \mathrm{M}$ tetrabutylammonium iodide (TBAI), $0.1 \mathrm{M} \mathrm{LiI}, 0.05 \mathrm{M} \mathrm{I}_{2}, 0.6 \mathrm{M}$ DMPII, and $0.5 \mathrm{M}$ 4-tertbutylpyridine (TBP) in dry acetonitrile (ACN) as electrolyte.

Under the standard global AM 1.5 solar condition, the D1 cell had a short circuit photocurrent density $\left(J_{\mathrm{sc}}\right)$ of $5.76 \mathrm{~mA} \cdot \mathrm{cm}^{-2}$, an open-circuit voltage $\left(V_{\mathrm{oc}}\right)$ of $0.595 \mathrm{~V}$, and a fill factor of 0.71 , corresponding to an overall conversion efficiency of $2.43 \%$. Under similar conditions, the photovoltaic parameters $\left(J_{\mathrm{sc}}, V_{\mathrm{oc}}\right.$, and $\left.\eta\right)$ of cells with the $\mathbf{D 2}$ sensitizer are $8.28 \mathrm{~mA} \cdot \mathrm{cm}^{-2}, 0.62 \mathrm{~V}$, and $3.49 \%$, respectively, those of the $\mathbf{D 3}$ sensitizer are $13.35 \mathrm{~mA} \cdot \mathrm{cm}^{-2}, 0.669 \mathrm{~V}$, and $5.53 \%$, respectively, and those of the D4 sensitizer are $8.09 \mathrm{~mA} \cdot \mathrm{cm}^{-2}, 0.628 \mathrm{~V}$, and $3.46 \%$, respectively. The great efficiency of the D3 sensitizer is probably due to the strong electron-donating ability of the phenothiazine unit when electrons transfer from the phenothiazine unit to the cyanoacrylic group. The solar-energy-to-electricity conversion efficiency of the present organic dyes could be improved by extending the conjugated length of organic dyes or incorporating a thiophene $\pi$-bridge. The synthesis of high efficiency organic dyes in our lab is still in progress. For the stability or long-term durability of presented organic dyes, the efficiencies of devices don't show obvious decay till $400 \mathrm{hr}$, the main contribution of DSSC efficiency decay after $400 \mathrm{hr}$ is the electrolyte. Furthermore, the larger $\mathrm{V}_{\text {oc }}$ of $\mathbf{D 3}$ is attributed to the retardation of charge recombination at the nanocrystallite/dye/redox electrolyte interface [37], the nonlinear $I-V$ curve observed in Figure 7 is intriguing, the schematic energy level diagram (Figure 4) for a DSSC based on D3 shows less energy gap between HOMO vs. $\left(\mathrm{I}^{-} / \mathrm{I}_{3}{ }^{-}\right)$redox potential than those of D1 and D2, this may result in slow diffusion current of main carrier and nonlinearity in $I-V$ curve. 
Figure 6. The incident photon-to-current conversion efficiency spectra for DSSCs based on D1-D4.

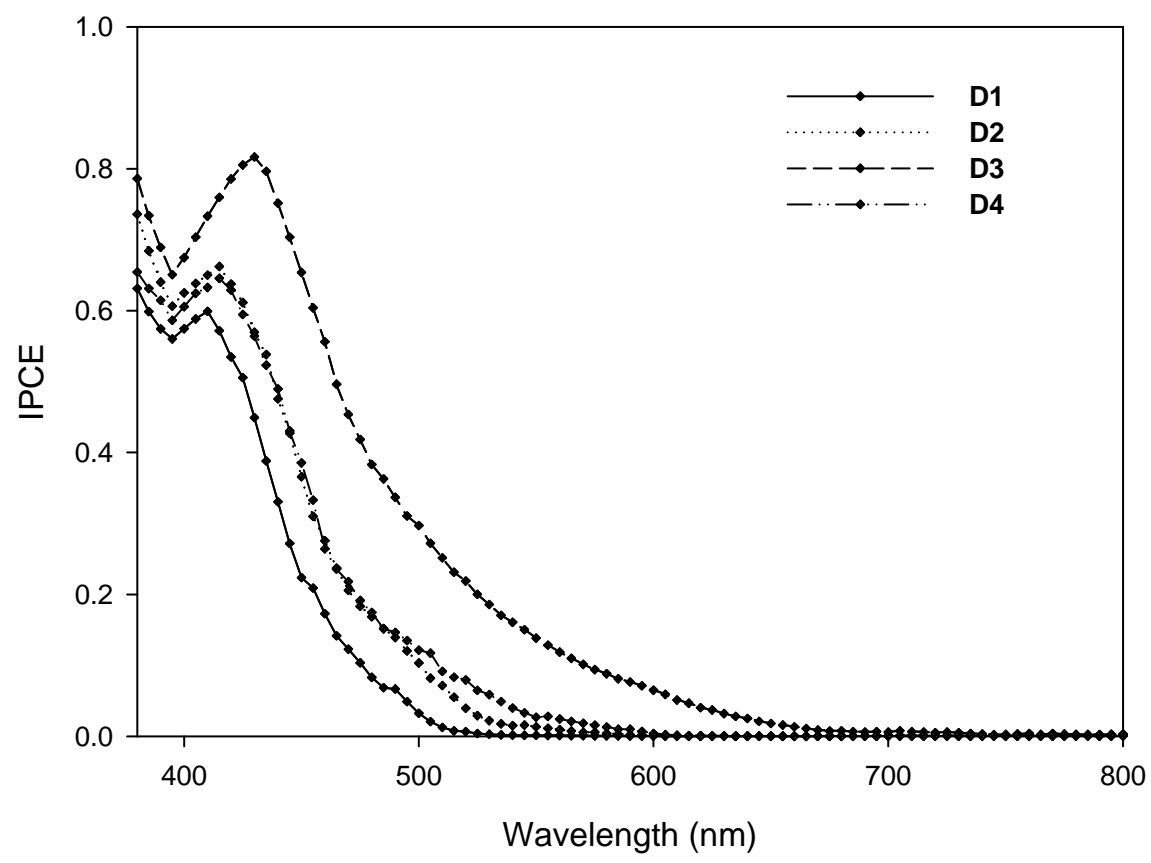

Figure 7. Current density-voltage characteristics for D1-D4 DSSCs under illumination of simulated solar light (AM 1.5, $100 \mathrm{~mW} \cdot \mathrm{cm}^{-2}$ ).

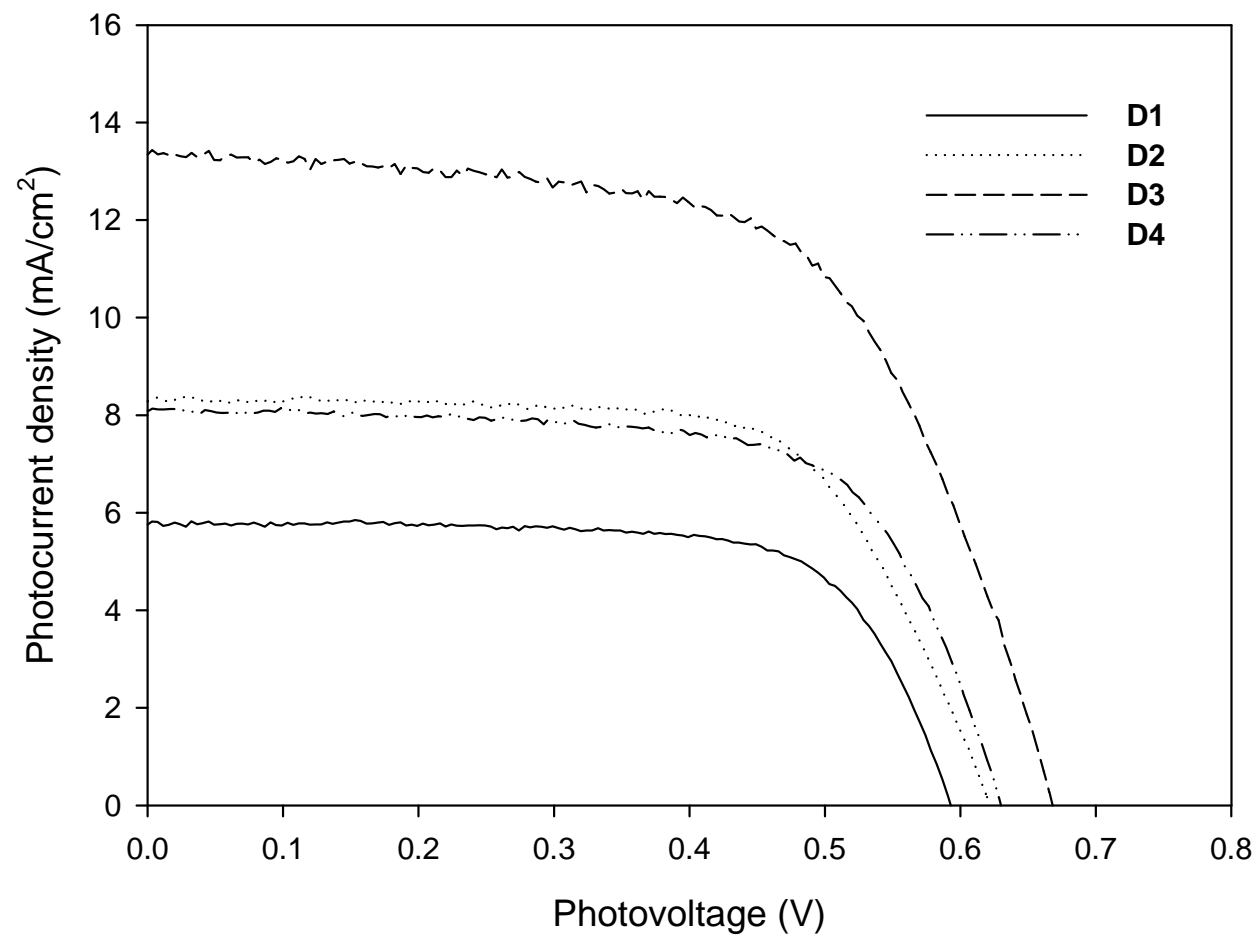




\subsection{The Transformation of Solar Energy into Electricity in Photovoltaic Devices}

The conversion of solar energy into electricity is attracting more attention as non-renewable energy reserves diminish. Dye sensitised solar cells consist of a nanostructured semiconductor film (e.g., $\sim 10 \mu \mathrm{m}$ anatase titania, Figure 8 ), coated with a monolayer of photoactive dye and an electrolyte bearing a redox couple (e.g., $\mathrm{I}_{3}^{-} / \mathrm{I}^{-}$). Sunlight enters the cell through the transparent glass plate striking the dye on the surface of the $\mathrm{TiO}_{2}$. Absorption of a photon of light by the dye promotes an electron is transferred from $\mathrm{S}^{\circ}$ to a higher lying energy level, then the sensitizer is in the excited state $\mathrm{S}^{*}$. The excited electron is injected into the conduction band of the semiconductor. A carboxyl group in D1-D4 can form an ester linkage with $\mathrm{TiO}_{2}$ surface to provide a strongly bound dye and a good electron communication between them.

The general operating principle of a dye-sensitized solar cell comprising a photoanode $\left(\mathrm{TiO}_{2}\right)$ and a passive cathode is depicted in Figure 9. The regenerative process in the dye solar cell consists of the following five steps, the process leads to photovoltaic performance in the solar cell.

(1) Electrons in dye are excited by solar energy adsorption.

(2) Electrons are transferred from dye to Indium tin oxide (ITO) conducting glass via $\mathrm{TiO}_{2}$.

(3) Electrons get to counter electrode after working at external load.

(4) $\mathrm{I}_{3}{ }^{-}+2 \mathrm{e}^{-} \rightarrow 3 \mathrm{I}^{-}$at counter electrode.

(5) $3 \mathrm{I}^{-} \rightarrow \mathrm{I}_{3}^{-}+2 \mathrm{e}^{-}$at dye.

Figure 8. Photovoltaic devices for the transformation of solar energy into electricity.

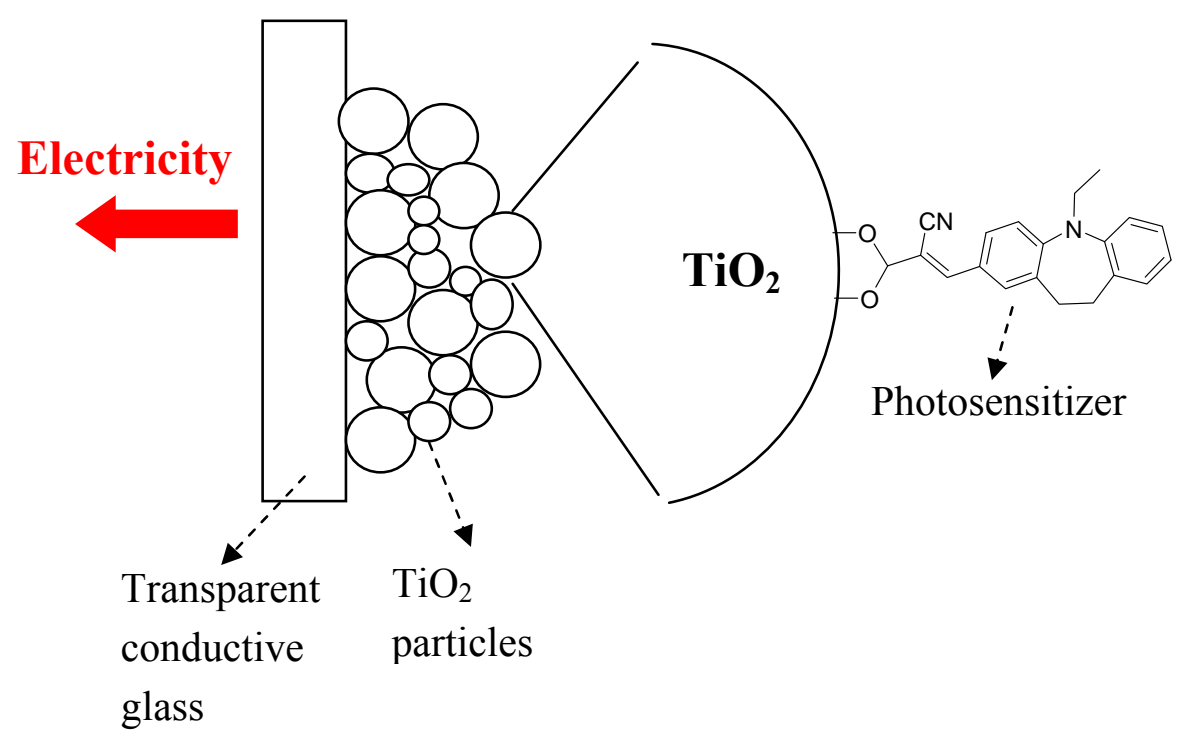


Figure 9. Energy diagram mechanism for a DSSC based on the D2 photosensitizer, $\mathrm{I}^{-} / \mathrm{I}_{3}{ }^{-}$ redox electrolyte, $\mathrm{TiO}_{2}$ anode, and $\mathrm{Pt}$ cathode.

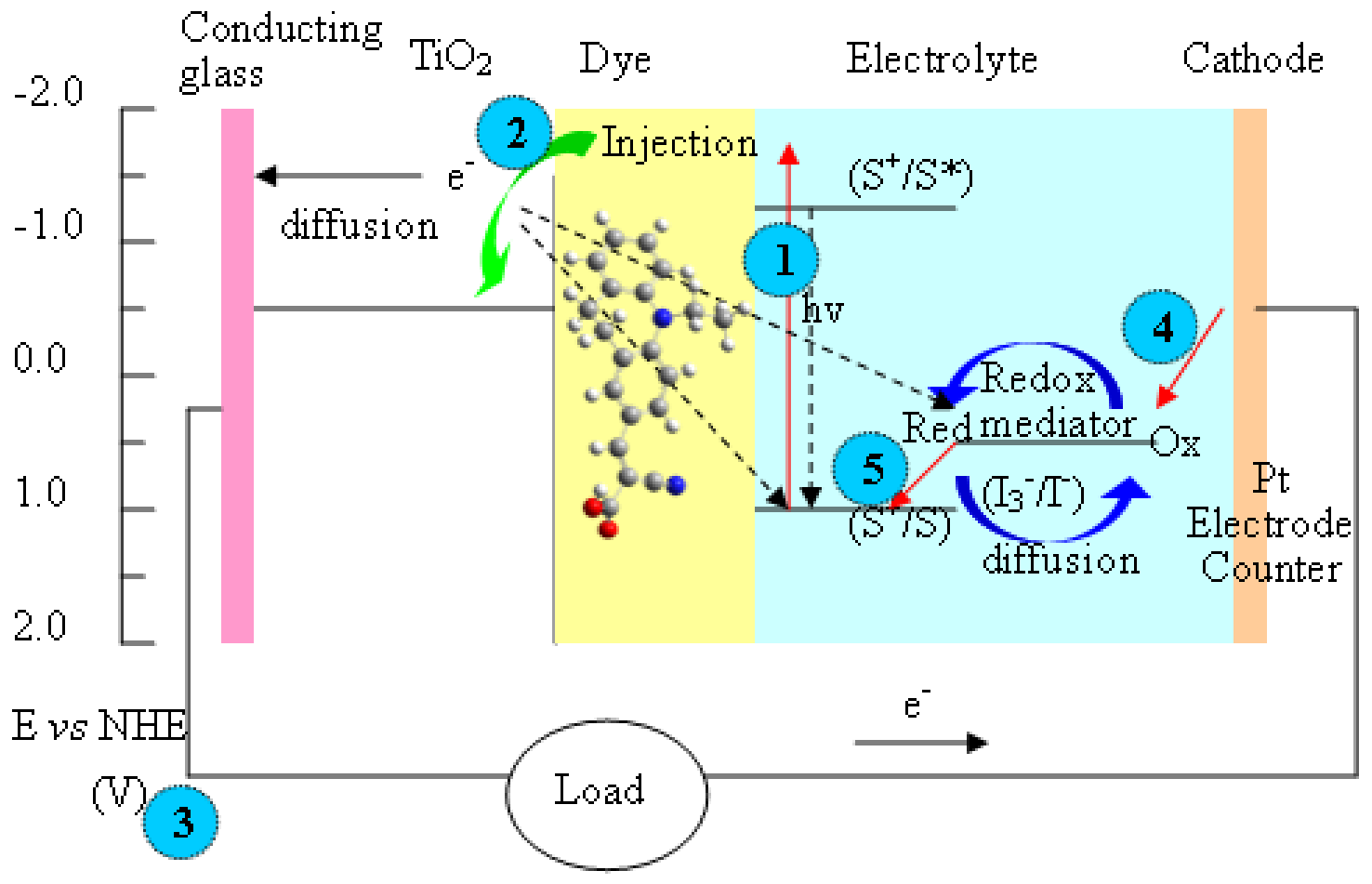

\section{Experimental Section}

\subsection{Chemicals}

All starting materials were purchased from Aldrich, Lancaster, TCI, and Acros and used as received. DMF, dichloromethane, and $\mathrm{POCl}_{3}$ were distilled from $\mathrm{CaH}_{2}$ under $\mathrm{N}_{2}$ atmosphere. Tetrabutylammonium perchlorate (TBAP) and 1,2-dimethyl-3-propylimidazolium iodide (DMPImI) were synthesized and purified according to a procedure described in the literature [38].

\subsection{Instrumentation}

The ${ }^{1} \mathrm{H}-\mathrm{NMR}$ spectra were obtained on a Bruker $400 \mathrm{MHz}$ FT-NMR. Chemical shifts are reported in ppm relative to tetramethylsilane $\delta$ units. The absorption spectra of the dyes in solution and adsorbed on $\mathrm{TiO}_{2}$ films were recorded on a Cary $100 \mathrm{UV}$-vis spectrophotometer. Fluorescence measurements were carried out using a Hitachi F-4500 fluorescence spectrophotometer. Cyclic voltammetry was performed using an electrochemical workstation $(\mathrm{CH}$ instruments Inc., $\mathrm{CHI}$, model 750A) and conducted in $\mathrm{CH}_{3} \mathrm{CN}$ solution using $0.1 \mathrm{M}$ tetrabutylammonium perchlorate (TBAP) as the supporting electrolyte. The working electrode was a glassy carbon electrode, the auxillary electrode was a Pt wire, and the reference electrode was $\mathrm{Ag} / \mathrm{Ag}^{+}$. The scan rate was $100 \mathrm{mv} \cdot \mathrm{s}^{-1}$ and the temperature was $25{ }^{\circ} \mathrm{C}$. Ferrocene was added to each sample solution at the end of the experiments. The ferrocenium/ferrocene $\left(\mathrm{Fc} / \mathrm{Fc}^{+}\right)$redox couple was used as an internal potential reference. The potential versus SCE in acetonitrile was calibrated according to a procedure published by Matsui et al. [39]. 
3.3. Synthetic Procedure of Carbazole, Iminodibenzyl, and Phenothiazine-containing Dyes D1-D4 (Figure 10)

Figure 10. Synthesis of the dyes D1-D4.<smiles>c1ccc2c(c1)[nH]c1ccccc12</smiles>

1

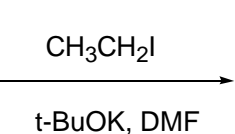

t-BuOK, DMF

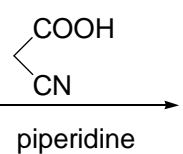

piperidine<smiles>CCn1c2ccccc2c2cc(/C=C(\C#N)C(=O)O)ccc21</smiles>

D1

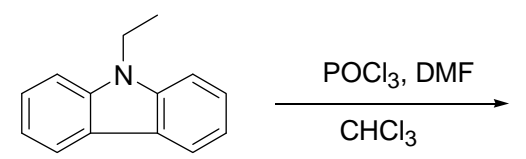

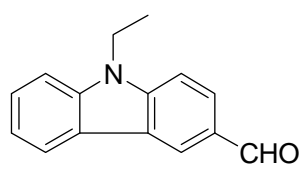

3

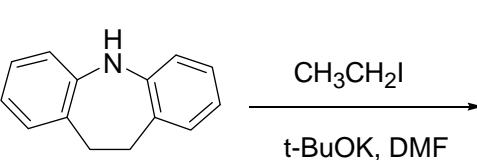

4

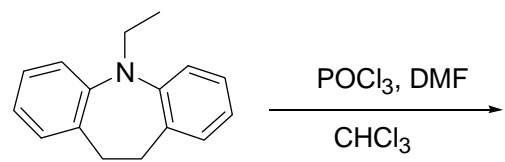

5

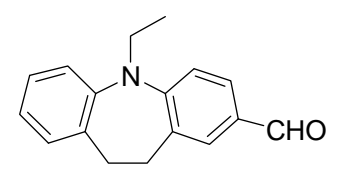

6<smiles>[R20]Cc1cc(/C=C(\C#N)C(=O)O)ccc1N(CC)c1ccccc1CC</smiles><smiles>CCOC(C)(C)C</smiles>

7<smiles>CCN1c2ccccc2Sc2ccccc21</smiles>

8

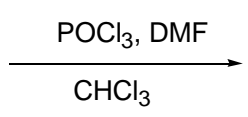

$\mathrm{CHC}_{3}$

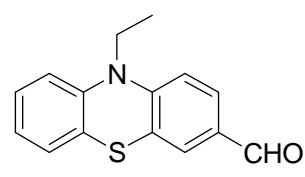

9

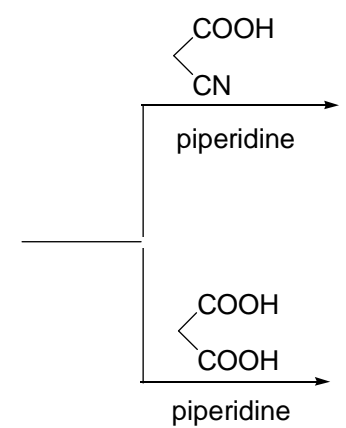<smiles>CCN1c2ccccc2Sc2cc(/C=C(\C#N)C(=O)O)ccc21</smiles>

D3<smiles>CCN1c2ccccc2Sc2cc(/C=C/C(=O)O)ccc21</smiles>

D4

\subsubsection{1-Ethyliminodibenzyl (5)}

Iminodibenzyl (4: $6.834 \mathrm{~g}, 35 \mathrm{mmol})$, iodoethane (5.93 g, $38 \mathrm{mmol})$, and DMF (80 mL) were added to a $50-\mathrm{mL}$ two-necked glass reactor. The solution was warmed to $75{ }^{\circ} \mathrm{C}$ and treated portionwise with potassium tert-butoxide $(4.264 \mathrm{~g}, 38 \mathrm{mmol})$, and then refluxed for $24 \mathrm{~h}$. After water $(150 \mathrm{~mL})$ was added, the mixture was extracted with chloroform $(75 \mathrm{~mL})$. Crude oils obtained by removing the solvent were purified by column chromatography (silica gels, $n$-hexane/ethyl acetate: 20:1 as eluent) to 
give 5 as a white solid (4.76 g, 61\%). ${ }^{1} \mathrm{H}-\mathrm{NMR}\left(\mathrm{CDCl}_{3}\right), \delta(\mathrm{ppm}): 1.16\left(\mathrm{t}, 3 \mathrm{H}, \mathrm{CH}_{3}\right), 3.17(\mathrm{~m}, 4 \mathrm{H}$, $\mathrm{CH}_{2}$ ), $3.80\left(\mathrm{~m}, 2 \mathrm{H}, \mathrm{CH}_{2}\right), 6.92\left(\mathrm{~m}, 2 \mathrm{H}\right.$, ar), $7.12\left(\mathrm{~m}, 6 \mathrm{H}\right.$, ar); Elem. Anal. Calcd. for $\mathrm{C}_{16} \mathrm{H}_{17} \mathrm{~N}$ : $\mathrm{C}$, $86.05 \%$; H, 7.67\%; N, 6.27\%. Found: C, 85.96\%; H, 7.73\%; N, 6.20\%.

\subsubsection{1-Ethyl-3-formyliminodibenzyl (6)}

$\mathrm{POCl}_{3}(7.4 \mathrm{~g}, 48 \mathrm{~mol})$ was added dropwise to freshly distilled $N, N$-dimethylformamide (4.3 g, $58 \mathrm{mmol}$ ) at $0{ }^{\circ} \mathrm{C}$ under a nitrogen atmosphere. A solution of 11-ethyl-iminodibenzyl (5: $3.35 \mathrm{~g}$, $15 \mathrm{mmol})$ in $N, N$-dimethylformamide $(4 \mathrm{~mL})$ was added dropwise to the $\mathrm{POCl}_{3} / \mathrm{DMF}$ complex at $30{ }^{\circ} \mathrm{C}$. The reaction mixture was stirred at $80{ }^{\circ} \mathrm{C}$ for $4 \mathrm{~h}$. When the reaction was finished (TLC monitoring), the reaction mixture was cooled to room temperature and poured into ice water. The obtained mixture was neutralized with $\mathrm{NaOH}$ until $\mathrm{pH}=7-8$. The precipitates were separated by filtration and washed with methanol. The crude product was purified by column chromatography (eluent: ethylacetate-hexane, 1:6). Yield of 6: $3.2 \mathrm{~g}(85 \%) ;{ }^{1} \mathrm{H}-\mathrm{NMR}\left(\mathrm{CDCl}_{3}\right), \delta$ (ppm): 1.07 (t, 3H, $\left.\mathrm{CH}_{3}\right), 3.11\left(\mathrm{~m}, 4 \mathrm{H}, \mathrm{CH}_{2}\right), 3.85\left(\mathrm{~m}, 2 \mathrm{H}, \mathrm{CH}_{2}\right), 7.00-7.08(\mathrm{~m}, 1 \mathrm{H}$, ar), 7.19-7.28 (m, 4H, ar), 7.57 (s, $1 \mathrm{H}$, ar), 7.64-7.67 (m, 1H, ar), $9.78(\mathrm{~s}, 1 \mathrm{H}, \mathrm{CHO})$; Elem. Anal. Calcd. for $\mathrm{C}_{17} \mathrm{H}_{17} \mathrm{NO}: \mathrm{C}, 81.24 \%$; $\mathrm{H}$, $6.82 \%$; N, 5.57\%. Found: C, 81.04\%; H, 6.90\%; N, 5.46\%.

\subsubsection{2-Cyano-3-(11-ethyliminodibenzyl-2-yl)-acrylic acid (D2)}

A mixture of 6 (1.005 g, $4 \mathrm{mmol})$ and cyanoacetic acid $(0.68 \mathrm{~g}, 8 \mathrm{mmol})$ was vacuum-dried. Acetonitrile $(20 \mathrm{~mL})$ and piperidine $(0.341 \mathrm{~g}, 4 \mathrm{mmol})$ were added to the mixture. The solution was refluxed for $6 \mathrm{~h}$. After the solution was cooled, the organic layer was removed in vacuo. The pure product was obtained by silica gel chromatography using EA:MeOH $=10: 1$ as eluent to afford D2 $(0.599 \mathrm{~g})$ in 47\% yield; ${ }^{1} \mathrm{H}-\mathrm{NMR}\left(\mathrm{DMSO}_{-} \mathrm{d}_{6}\right), \delta(\mathrm{ppm}): 1.06\left(\mathrm{t}, 3 \mathrm{H}, \mathrm{CH}_{3}\right), 3.05\left(\mathrm{~m}, 4 \mathrm{H}, \mathrm{CH}_{2}\right)$, $3.79\left(\mathrm{~m}, 2 \mathrm{H}, \mathrm{CH}_{2}\right), 7.00(\mathrm{~m}, 1 \mathrm{H}), 7.16(\mathrm{~m}, 4 \mathrm{H}), 7.53(\mathrm{~s}, 1 \mathrm{H}), 7.73(\mathrm{~d}, 1 \mathrm{H}), 7.86(\mathrm{~s}, 1 \mathrm{H})$; Elem. Anal. Calcd. for $\mathrm{C}_{20} \mathrm{H}_{18} \mathrm{~N}_{2} \mathrm{O}_{2}$ : C, 75.45\%; H, 5.70\%; N, 8.80\%. Found: C, 75.16\%; H, 5.59\%; N, 8.60\%.

\subsubsection{0-Ethyl-phenothiazine (8)}

Phenothiazine (7: $11.94 \mathrm{~g}, 60 \mathrm{mmol})$, iodoethane (10.92 g, $70 \mathrm{mmol})$, and DMF (80 mL) were added to a $50-\mathrm{mL}$ two-necked glass reactor. The solution was warmed to $75^{\circ} \mathrm{C}$, treated portionwise with potassium tert-butoxide $(7.86 \mathrm{~g}, 70 \mathrm{mmol})$, and then refluxed for $24 \mathrm{~h}$. After water $(150 \mathrm{~mL})$ was added, the mixture was extracted with chloroform $(75 \mathrm{~mL})$. Crude oils obtained by removing the solvent were purified by column chromatography (silica gels, $n$-hexane/ethyl acetate: 20:1 as eluent) to give 8 as a white solid (11.32 g, yield: 83\%). MP: 103-104 ${ }^{\circ} \mathrm{C} ;{ }^{1} \mathrm{H}-\mathrm{NMR}\left(\mathrm{CDCl}_{3}\right), \delta(\mathrm{ppm}): 1.42(\mathrm{t}$, $\left.3 \mathrm{H}, \mathrm{CH}_{3}\right), 3.92\left(\mathrm{~m}, 2 \mathrm{H}, \mathrm{CH}_{2}\right), 6.85-6.88(\mathrm{~m}, 4 \mathrm{H}, \mathrm{ar}), 7.11-7.16(\mathrm{~m}, 4 \mathrm{H}, \mathrm{ar})$; Elem. Anal. Calcd. for $\mathrm{C}_{14} \mathrm{H}_{13} \mathrm{NS}$ : C, 73.97\%; H, 5.76\%; N, 6.16\%; S, 14.11\%. Found: C, 73.83\%; H, 5.73\%; N, 6.13\%, S: $14.10 \%$.

\subsubsection{0-Ethyl-3-formylphenothiazine (9)}

$\mathrm{POCl}_{3}(14.8 \mathrm{~g}, 0.097 \mathrm{~mol})$ was added dropwise to freshly distilled $N, N$-dimethylformamide $(8.6 \mathrm{~g}$, $0.116 \mathrm{~mol}$, molar ratio $1: 1.2)$ at $0{ }^{\circ} \mathrm{C}$ in nitrogen atmosphere. A solution of $N$-ethylphenothiazine $(\mathbf{8}$, 
$6.8 \mathrm{~g}, 0.03 \mathrm{~mol})$ in $\mathrm{N}, \mathrm{N}$-dimethylformamide $\left(8 \mathrm{~mL}\right.$ ) was added dropwise to the $\mathrm{POCl}_{3} / \mathrm{DMF}$ complex at $30{ }^{\circ} \mathrm{C}$. The reaction mixture was stirred at $80{ }^{\circ} \mathrm{C}$ for $4 \mathrm{~h}$. When the reaction was finished (TLC monitoring), the reaction mixture was cooled to room temperature and poured into ice water. The obtained mixture was neutralized with $\mathrm{NaOH}$ until $\mathrm{pH}=7-8$. The precipitates were separated by filtration and washed with methanol. The crude product was purified by column chromatography (eluent: ethyl acetate/hexane, 1:6). Yield of 9: $5.36 \mathrm{~g} \mathrm{(70 \% );}{ }^{1} \mathrm{H}-\mathrm{NMR}\left(\mathrm{CDCl}_{3}\right), \delta$ (ppm): $1.45(\mathrm{t}, 3 \mathrm{H}$, $\left.\mathrm{CH}_{3}\right), 3.98\left(\mathrm{~m}, 2 \mathrm{H}, \mathrm{CH}_{2}\right), 6.88-6.98$ (m, 3H, ar), 7.09-7.19 (m, 2H, ar), 7.57-7.65 (m, 2H, ar), 9.80 (s, 1H, CHO); Elem. Anal. Calcd. for $\mathrm{C}_{15} \mathrm{H}_{13} \mathrm{NOS}$ : C, 70.56\%; H, 5.13\%; N, 5.49\%, S, 12.56\%. Found: C, 70.49\%; H, 5.26\%; N, 5.37\%, S, 12.38\%.

\subsubsection{2-Cyano-3-(10-ethylphenothiazin-3-yl)-acrylic acid (D3)}

A mixture of 9 (2.01 g, $8 \mathrm{mmol})$ and cyanoacetic acid (1.36 g, $16 \mathrm{mmol})$ were vacuum-dried. Acetonitrile $(40 \mathrm{~mL})$ and piperidine $(0.68 \mathrm{~g}, 8 \mathrm{mmol})$ were added to the mixture. The solution was refluxed for $6 \mathrm{~h}$. After the solution was cooled, the organic layer was removed in vacuo. The pure product was obtained by silica gel chromatography using EA:MeOH $=10: 1$ as eluent to afford D3 $(1.31 \mathrm{~g})$ in 51\% yield; ${ }^{1} \mathrm{H}-\mathrm{NMR}\left(\mathrm{DMSO}_{-} \mathrm{d}_{6}\right), \delta(\mathrm{ppm}): 1.29\left(\mathrm{t}, 3 \mathrm{H}, \mathrm{CH}_{3}\right), 3.91(\mathrm{~m}, 2 \mathrm{H}), 6.94-7.23(\mathrm{~m}$, 5H), 7.65-8.07 (m, 3H); Elem. Anal. Calcd. for $\mathrm{C}_{18} \mathrm{H}_{14} \mathrm{~N}_{2} \mathrm{O}_{2} \mathrm{~S}: \mathrm{C}, 67.06 \%$; $\mathrm{H}, 4.38 \%$; N, 8.69\%, S, 9.95\%. Found: C, 66.78\%; H, 4.30\%; N, 8.50\%, S, 9.81\%.

\subsubsection{3-(10-Ethylphenothiazin-3-yl)-acrylic acid (D4)}

10-Ethyl-3-formylphenothiazine (9, $0.45 \mathrm{~g}, 1.76 \mathrm{mmol})$, malonic acid (0.55 g, $5.28 \mathrm{~mol})$, in pyridine $(5 \mathrm{~mL})$ were mixed with four drops of piperidine. The reaction was stirred at $90{ }^{\circ} \mathrm{C}$ for $2 \mathrm{~h}$, followed by adjustment of $\mathrm{pH}=2$ with $\mathrm{HCl}$ solution. A crude product was obtained and recrystallized from toluene and dried under vacuum. Yield was 91\%; ${ }^{1} \mathrm{H}-\mathrm{NMR}\left(\mathrm{Me}_{2} \mathrm{SO}-d_{6}\right), \delta(\mathrm{ppm}): 1.29(\mathrm{t}, 3 \mathrm{H}$, $\left.\mathrm{CH}_{3}\right), 3.93\left(\mathrm{~m}, 2 \mathrm{H}, \mathrm{CH}_{2}\right), 6.38(\mathrm{~d}, 1 \mathrm{H}, \mathrm{C}=\mathrm{CH}), 6.92-7.04(\mathrm{~m}, 3 \mathrm{H}), 7.11-7.22(\mathrm{~m}, 2 \mathrm{H}), 7.44-7.49$ (m, $3 \mathrm{H}$ ); Elem. Anal. Calcd. for $\mathrm{C}_{17} \mathrm{H}_{15} \mathrm{NO}_{2} \mathrm{~S}: \mathrm{C}, 68.66 \%$; $\mathrm{H}, 5.08 \%$; N, 4.71\%, S, 10.78\%. Found: C, $68.57 \% ; \mathrm{H}, 5.18 \%$; N $4.72 \%$, S, $10.70 \%$.

\subsubsection{2-Cyano-3-(9-ethylcarbazol-3-yl)-acrylic acid (D1)}

9-Ethylcarbazole (2) and 9-ethyl-3-formylcarbazole (3) were synthesized with the procedures used for compounds $\mathbf{5}$ and $\mathbf{6}$, respectively. A mixture of 9-ethyl-3-formylcarbazole (3, $2.01 \mathrm{~g}, 9 \mathrm{mmol})$ and cyanoacetic acid (1.36 g, $16 \mathrm{mmol})$ were vacuum-dried. Acetonitrile $(40 \mathrm{~mL})$ and piperidine $(0.68 \mathrm{~g}, 8 \mathrm{mmol})$ were added to the mixture. The solution was refluxed for $6 \mathrm{~h}$. After the solution was cooled, the organic layer was removed in vacuo. The pure product was obtained by silica gel chromatography using EA/MeOH $=10: 1$ as eluent to afford D1 (1.25 g) in 48\% yield; ${ }^{1} \mathrm{H}-\mathrm{NMR}$ (DMSO-d $\left.\mathrm{D}_{6}\right), \delta(\mathrm{ppm}): 1.33\left(\mathrm{t}, 3 \mathrm{H}, \mathrm{CH}_{3}\right), 4.49\left(\mathrm{~m}, 2 \mathrm{H}, \mathrm{CH}_{2}\right), 7.27(\mathrm{t}, 1 \mathrm{H}), 7.52(\mathrm{t}, 1 \mathrm{H}), 7.66-7.76(\mathrm{~m}$, $2 \mathrm{H}), 8.15$ (m, 3H), 8.67 (s, 1H); Elem. Anal. Calcd. for $\mathrm{C}_{18} \mathrm{H}_{14} \mathrm{~N}_{2} \mathrm{O}_{2}$ : C, 74.47\%; H, 4.86\%; N, 9.65\%. Found: C, 74.16\%; H, 4.76\%; N, 9.55\%. 


\subsection{Preparation of Dye-sensitized $\mathrm{TiO}_{2}$ Electrode (Photoanode) and Counter Electrode}

The working $\mathrm{TiO}_{2}$ electrode (photoanode) and counter electrode for dye-sensitized solar cells were prepared as follows. F-doped tin oxide (FTO) glass plates ( $3 \mathrm{~mm}$ thickness, $7 \Omega \mathrm{cm}^{-2}$ ) were first cleaned in a cleaning detergent aqueous solution with an ultrasonic bath for $15 \mathrm{~min}$, and rinsed with water and ethanol. Then, the FTO electrodes were immersed into $40 \mathrm{mM} \mathrm{TiCl}_{4}$ (aqueous) at $70{ }^{\circ} \mathrm{C}$ for $30 \mathrm{~min}$ and rinsed with water and ethanol. Two kinds of $\mathrm{TiO}_{2}$ paste, containing nanocrystalline ( $25 \mathrm{~nm}$ ) $\mathrm{TiO}_{2}$ (Degussa $\mathrm{P} 25$, paste A) and submicroparticle $\mathrm{TiO}_{2}$ (paste $\mathrm{B}, 500 \mathrm{~nm}$ ), respectively, were prepared using a previously reported procedure [40]. To prepare paste A, commercial titania powder ( $3 \mathrm{~g}$, Degussa P25) was ground in a mortar with a small amount of water $(1 \mathrm{~mL})$ containing acetylacetone $(0.1 \mathrm{~mL})$, which was added to prevent reaggregation of the particles. After the $\mathrm{TiO}_{2}$ particles were dispersed, the paste was diluted by the slow addition of water $(3 \mathrm{~mL})$ under continued grinding and a surfactant, Triton X-100 $(0.05 \mathrm{~mL})$, was added to facilitate the spreading of the colloid on the substrate. Paste A was sonicated for about $24 \mathrm{~h}$ at $28^{\circ} \mathrm{C}$. The spin coating procedure for paste A was repeated to get the appropriate thickness of $\mathrm{TiO}_{2}$ films $(12 \mu \mathrm{m})$. After paste A was dried at $125^{\circ} \mathrm{C}$, paste $\mathrm{B}$ was coated two more times, which made the thickness of the $\mathrm{TiO}_{2}$ films with $500 \mathrm{~nm}$ particles for the scattering layer $\sim 4 \mu \mathrm{m}$. The electrodes coated with $\mathrm{TiO}_{2}$ pastes were gradually heated $\left(5{ }^{\circ} \mathrm{C} \mathrm{min}{ }^{-1}\right)$ under airflow up to $450{ }^{\circ} \mathrm{C}$, which was kept for $30 \mathrm{~min}$. The electrodes were treated with $40 \mathrm{mM} \mathrm{TiCl}_{4}$. The $\mathrm{TiO}_{2}$ films were then rinsed with water and ethanol and sintered again at $450{ }^{\circ} \mathrm{C}$ for $30 \mathrm{~min}$. An active area of $0.5 \mathrm{~cm} \times 0.5 \mathrm{~cm}$ was selected from a sintered electrode. The electrodes were immersed in a $3 \times 10^{-4} \mathrm{M}$ solution of dye containing acetonitrile and isoporpanol (in a volume ratio of 1:1). Dye coatings were applied at room temperature for 24-30 h. The dye-adsorbed $\mathrm{TiO}_{2}$ films were taken out and rinsed with dry ethanol. The rinsing process was repeated several times to remove unbound dyes completely. Finally, the dye-adsorbed $\mathrm{TiO}_{2}$ films were dried in air. A counter electrode was prepared by sputtering a thin platinum layer on an FTO substrate. The thickness of the Pt layer was controlled to be $50 \mathrm{~nm}$. The thicknesses of the $\mathrm{TiO}_{2}$ films were determined by profilometry. Platinum sputtering was carried out using a Hitachi E 1045 instrument. The platinum layer thickness of on the glass substrates was estimated using the amount of sputtered platinum recorded on a quartz thickness monitor.

\subsection{DSSC Assembly}

The dye adsorbed $\mathrm{TiO}_{2}$ electrode and Pt-counter electrode were assembled into a sandwich sealed type cell by heating them with hot-melt ionomer film ( $25 \mu \mathrm{m}$ thickness, Solaronix $)$ as a spacer. A drop of electrolyte solution [0.1 M LiI, 0.05 $\mathrm{M} \mathrm{I}_{2}$, 0.6 M DMPII, 0.5 M tert-butyl pyridine (TBP) in acetonitile $(\mathrm{ACN})$ ] was injected through a hole in the counter electrode, which was then sealed with hot-melt ionomer film and glass. The electrolyte was introduced into the cell and sealed with $\mathrm{AB}$ epoxy for $30 \mathrm{~min}$. The working area of the electrode was $0.25 \mathrm{~cm}^{2}$.

\subsection{Photovoltaic Measurements of the Solar Cells}

The photovoltaic measurements of the DSSCs were performed using a Newport M-66907 $450 \mathrm{~W}$ xenon light source through an infrared blocking filter and a Keithley 2,400 digital source meter linked 
to a computerized control and data acquisition system. The light intensity was $1000 \mathrm{~W} \cdot \mathrm{m}^{-2}$ under an AM 1.5 light source. Cell temperatures were kept at $25^{\circ} \mathrm{C}$ during the illumination. Light intensity was calibrated using a mono-Si reference solar cell (PVM134). The incident photon-to-current conversion efficiency (IPCE) as a function of excitation wavelength was measured using an incident light $300 \mathrm{~W}$ xenon lamp. A 300W xenon arc lamp solar simulator (\#91160A, Oriel) with an AM 1.5 Globe filter (\#59044, Oriel) was used to measure the I-V characteristics of the quasi-solid-state DSSC. The illumination was fixed at $100 \mathrm{~mW} \cdot \mathrm{cm}^{-2}$ using a reference solar cell and meter (\#91150, Oriel).

\subsection{Computation Methods}

D1-D4 are the carbazole, iminodibenzyl, and phenothiazine-containing dyes, respectively. The geometric and electronic properties of sensitizers D1-D4 were obtained using the Gaussian 03 program package [31]. The calculation was optimized using B3LYP (Becke three parameter hybrid function with Lee-Yang-Perdew gradient correlation functions) with the Pople 6-31 $+\mathrm{g}(\mathrm{d})$ atomic basis set. The excitation transitions of D1-D4 were calculated using time-dependent density functional theory (TD-DFT) calculations with B3LYP/6-31 + g(d). Molecular orbitals were visualized using Gaussview.

\section{Conclusions}

Four organic D- $\pi$-A dyes by employing various donors (carbazole, iminodibenzyl, and phenothiazine) and various acceptors (cyanoacrylic acid and acrylic acid) were designed and synthesized as the sensitizers for DSSC applications. Significant differences were noticed in the absorption and electrochemical behavior between the cyanoacrylic acid and acrylic acid-based dyes manifest in the DSSCs device performance. Electrochemistry along with DFT calculations revealed that the low-lying LUMO caused by the substitutions is the main reason for the narrowed HOMOLUMO gaps. The LUMO values of D1 $(-1.70 \mathrm{~V})$, D2 $(-2.14 \mathrm{~V}), \mathbf{D 3}(-1.92 \mathrm{~V})$, and D4 $(-2.04 \mathrm{~V})$ are more negative than the conduction band edge of $\mathrm{TiO}_{2}[-0.5 \mathrm{~V}$ (vs. NHE)]. The HOMO values of D1 $(1.14 \mathrm{~V}), \mathbf{D} 2(0.77 \mathrm{~V}), \mathbf{D 3}(0.52 \mathrm{~V})$, and $\mathbf{D} 4(0.54 \mathrm{~V})$ are sufficiently more positive than the $\mathrm{I}_{3}{ }^{-} / \mathrm{I}^{-}$ redox potential $[0.42 \mathrm{~V}(v s$. NHE)]. The density functional theory (DFT) calculations reveal that HOMO-LUMO excitation moves the electron density distribution from the donor (carbazole, iminodibenzyl, and phenothiazine) to the acceptor (cyanoacrylic acid and acrylic acid). A solar energy to electricity conversion efficiency of $5.53 \%$ is achieved for the phenothiazine and cyanoacrylic acid substituted dye D3, which is higher than the corresponding phenothiazine substituted donor-acceptor dye D4, and higher than the corresponding carbazole and iminodibenzyl substituted donor-acceptor dye (D1 and D2, respectively). Detailed experiments and the investigation of the interfacial charge transfer processes of these dyes are in progress aiming to further increase the performance of DSSCs fabricated with this new group of dyes.

\section{Acknowledgements}

The authors would like to thank the National Science Council of the Republic of China for financially supporting this project under grant: 96-2113-M-006-014-MY3. 


\section{References and Notes}

1. Staub, K.; Levina, G.A.; Fortd, A. Synthesis and stability studies of conformationally locked 4(diarylamino)aryl- and 4-(dialkylamino)phenyl-substituted second-order nonlinear optical polyene chromophores. J. Mater. Chem. 2003, 13, 825-833.

2. Tsai, Y.-L.; Chang, C.-C.; Kang, C.-C.; Chang, T.-C. Effect of different electronic properties on 9-aryl-substituted BMVC derivatives for new fluorescence probes. J. Lumin. 2007, 127, 41-47.

3. Yoon, K.R.; Ko, S.-O.; Lee, S.M.; Lee, H. Synthesis and characterization of carbazole derived nonlinear optical dyes. Dye Pig. 2007, 75, 567-573.

4. Li, W.; Qiao, J.; Duan, L.; Wang, L.D.; Qiu, Y. Novel fluorene/carbazole hybrids with steric bulk as host materials for blue organic electrophosphorescent devices. Tetrahedron 2007, 63, 10161-10168.

5. Li, X.H.; Gui, J.; Yang, H.; Wu, W.J.; Li, F.Y.; Tian, H.; Huang, C.H. A new carbazole-based phenanthrenyl ruthenium complex as sensitizer for a dye-sensitized solar cell. Inorg. Chim. Acta 2008, 361, 2835-2840.

6. Zhou, Y.H.; Peng, P.; Han, L.; Tian, W.J. Novel donor-acceptor molecules as donors for bulk heterojunction solar cells. Synth. Met. 2007, 157, 502-507.

7. Zhang, H.; Huo, C.; Zhang, J.; Zhang, P.; Tian, W.; Wang, Y. Efficient single-layer electroluminescent device based on a bipolar emitting boron-containing material. Chem. Commun. 2006, 3, 281-283.

8. Chattopadhyay, N. Excited state proton transfer of carbazole. A convenient way to study microheterogeneous environments. Int. J. Mol. Sci. 2003, 4, 460-480.

9. Croce, G.; Arrais, A.; Diana, E.; Civalleri, B.; Viterbo, D.; Milanesio, M. The interpretation of the short range disorder in the Fluorene-TCNE crystal structure. Int. J. Mol. Sci. 2004, 5, 93-100.

10. Koz, B.; Kiskan, B.; Yagci, Y. Synthesis and characterization of polyacetylene with side-chain thiophene functionality. Int. J. Mol. Sci. 2008, 9, 383-393.

11. Xiang, N.J.; Lee, T.H.; Gong, M.L.; Tong, K.L.; So, S.K.; Leung, L.M. Synthesis of 2-phenylquinoline-based ambipolar molecules containing multiple 1,3,4-oxadiazole spacer groups. Synth. Met. 2006, 156, 270-275.

12. Kulkarni, A.P.; Wu, P.-T.; Kwon, T.W.; Jenekhe, S.A. Phenothiazine-phenylquinoline donor-acceptor molecules: Effects of structural isomerism on charge transfer photophysics and electroluminescence. J. Phys. Chem. B 2005, 109, 19584-19594.

13. Gaina, L.; Cristea, C.; Moldovan, C.; Porumb, D.; Surducan, E.; Deleanu, C.; Mahamoud, A.; Barbe, J.; Silberg, I.A. Microwave-assisted synthesis of phenothiazine and quinoline derivatives. Int. J. Mol. Sci. 2007, 8, 70-80.

14. Xia, Y.; Luo, J.; Deng, X.; Li, X.; Li, D.; Zhu, X.; Yang, W.; Cao, Y. Novel random low-bandgap fluorene-based copolymers for deep red/near infrared light-emitting diodes and bulk heterojunction photovoltaic cells. Macromol. Chem. Phys. 2006, 207, 511-520.

15. Huo, L.; He, C.; Han, M.; Zhou, E.; Li, Y.F. Alternating copolymers of electron-rich arylamine and electron-deficient 2,1,3-benzothiadiazole: Synthesis, characterization and photovoltaic properties. J. Polym. Sci. Part A: Polym. Chem. 2007, 45, 3861-3871. 
16. Zhu, Y.; Kulkarni, A.P.; Jenekhe, S.A. Phenoxazine-based emissive donor-acceptor materials for efficient organic light-emitting diodes. Chem. Mater. 2005, 17, 5225-227.

17. Sun, X.B.; Liu, Y.Q.; Xu, X.J.; Yang, C.H.; Yu, G.; Chen, S.Y.; Zhao, Z.H.; Qiu, W.F.; Li, Y.F.; Zhu, D.B. Novel electroactive and photoactive molecular materials based on conjugated donor-acceptor structures for optoelectronic device applications. J. Phys. Chem. B 2005, 109, 10786-10792.

18. Mazumder, R.; Ganguly, K.; Dastidar, S.G.; Chakrabarty, A.N. Trifluoperazine: a broad spectrum bactericide especially active on staphylococci and vibrios. Int. J. Antimicrob. Agents 2001, 18, 403-406.

19. Khazraji, A.C.; Hotchandani, S.; Das, S.; Kamat, P.V. Controlling dye (Merocyanine-540) aggregation on nanostructured $\mathrm{TiO}_{2}$ films. An organized assembly approach for enhancing the efficiency of photosensitization. J. Phys. Chem. B 1999, 103, 4693-4700.

20. Hara, K.; Dan-oh, Y.; Kasada, C.; Ohga, Y.; Shinpo, A.; Suga, S.; Sayama, K.; Arakawa, H. Effect of additives on the photovoltaic performance of coumarin-dye-sensitized nanocrystalline $\mathrm{TiO}_{2}$ solar cells. Langmuir 2004, 20, 4205-4210.

21. Wang, Z.-S.; Hara, K.; Dan-oh, Y.; Kasada, C.; Shinpo, A.; Suga, S.; Arakawa, H.; Sugihara, H. Photophysical and (photo)electrochemical properties of a coumarin dye. J. Phys. Chem. B 2005, 109, 3907-3914.

22. Chen, Y.; Wu, T.-Y. Synthesis, optical and electrochemical properties of luminescent copolymers containing N-hexyl-3,8-iminodibenzyl chromophores. Polymer 2001, 42, 9895-9901.

23. Liang, M.; Xu, W.; Cai, F.; Chen, P.; Peng, B.; Chen, J.; Li, Z. New Triphenylamine-based organic dyes for efficient dye-sensitized solar cells. J. Phys. Chem. C 2007, 111, 4465-4472.

24. Hara, K.; Kurashige, M.; Dan-oh, Y.; Kasada, C.; Shinpo, A.; Suga, S.; Sayama, K.; Arakawa, H. Design of new coumarin dyes having thiophene moieties for highly efficient organic-dyesensitized solar cells. New J. Chem. 2003, 27, 783-785.

25. Nazeeruddin, M.K.; Kay, A.; Rodicio, I.; Humpbry-Baker, R.; Miiller, E.; Liska, P.; Vlachopoulos, N.; Grätzel, M. Conversion of light to electricity by cis- $\mathrm{X}_{2}$ bis(2,2'-bipyridyl-4,4'dicarboxylate)ruthenium(II) charge-transfer sensitizers $\left(\mathrm{X}=\mathrm{Cl}^{-}, \mathrm{Br}^{-}, \mathrm{I}^{-}, \mathrm{CN}^{-}\right.$, and $\left.\mathrm{SCN}^{-}\right)$on nanocrystalline titanium dioxide electrodes. J. Am. Chem. Soc. 1993, 115, 6382-6390.

26. Lai, R.Y.; Fabrizio, E.F.; Lu, L.; Jenekhe, S.A.; Bard, A.J. Synthesis, cyclic voltammetric studies, and electrogenerated chemiluminescence of a new donor - acceptor molecule: 3,7-[Bis[4-phenyl2-quinolyl]]-10-methylphenothiazine. J. Am. Chem. Soc. 2001, 123, 9112-9118.

27. Chen, K.F.; Hsu, Y.C.; Wu, Q.Y.; Yeh, M.C.P.; Sun, S.S. Structurally simple dipolar organic dyes featuring 1,3-Cyclohexadiene conjugated unit for dye-sensitized solar cells. Org. Lett. 2009, 11, $377-380$.

28. Lai, R.Y.; Kong, X.; Jenekhe, S.A.; Bard, A.J. Synthesis, cyclic voltammetric studies, and electrogenerated chemiluminescence of a new phenylquinoline-biphenothiazine donor-acceptor molecule. J. Am. Chem. Soc. 2003, 125, 12631-12639.

29. Hagfeldt, A.; Grätzel, M. Light-induced redox reactions in nanocrystalline systems. Chem. Rev. 1995, 95, 49-68.

30. Ito, S.; Zakeeruddin, S.M.; Humphry-Baker, R.; Liska, P.; Charvet, R.; Comte, P.; Nazeeruddin, M.K.; Péchy, P.; Takata, M.; Miura, H.; Uchida, S.; Grätzel, M. High-efficiency organic-dye- 
sensitized solar cells controlled by nanocrystalline- $\mathrm{TiO}_{2}$ electrode thickness. Adv. Mater. 2006, 18, $1202-1205$.

31. Frisch, M.J.; Trucks, G.W.; Schlegel, H.B.; Scuseria, G.E.; Robb, M.A.; Cheeseman, J.R., Jr.; Montgomery, J.A.; Vreven, T.; Kudin, K.N.; Burant, J.C.; Millam, J.M.; Iyengar, S.S.; Tomasi, J.; Barone, V.; Mennucci, B.; Cossi, M.; Scalmani, G.; Rega, N.; Petersson, G.A.; Nakatsuji, H.; Hada, M.; Ehara, M.; Toyota, K.; Fukuda, R.; Hasegawa, J.; Ishida, M.; Nakajima, T.; Honda, Y.; Kitao, O.; Nakai, H.; Klene, M.; Li, X.; Knox, J.E.; Hratchian, H.P.; Cross, J.B.; Adamo, C.; Jaramillo, J.; Gomperts, R.; Stratmann, R.E.; Yazyev, O.; Austin, A.J.; Cammi, R.; Pomelli, C.; Ochterski, J.W.; Ayala, P.Y.; Morokuma, K.; Voth, G.A.; Salvador, P.; Dannenberg, J.J.; Zakrzewski, V.G.; Dapprich, S.; Daniels, A.D.; Strain, M.C.; Farkas, O.; Malick, D.K.; Rabuck, A.D.; Raghavachari, K.; Foresman, J.B.; Ortiz, J.V.; Cui, Q.; Baboul, A.G.; Clifford, S.; Cioslowski, J.; Stefanov, B.B.; Liu, G.; Liashenko, A.; Piskorz, P.; Komaromi, I.; Martin, R.L.; Fox, D.J.; Keith, T.; Al-Laham, M.A.; Peng, C.Y.; Nanayakkara, A.; Challacombe, M.; Gill, P.M.W.; Johnson, B.; Chen, W.; Wong, M.W.; Gonzalez, C.; Pople, J.A. Gaussian 03, Revision C.01; Gaussian Inc.: Wallingford, CT, USA, 2004.

32. Becke, A.D. Density-functional thermochemistry. III. The role of exact exchange. J. Chem. Phys. 1993, 98, 5648-5652.

33. Becke, A.D. Density-functional thermochemistry. I. The effect of the exchange-only gradient correction. J. Chem. Phys. 1992, 96, 2155-2160.

34. Lee, C.; Yang, W.; Parr, R.G. Development of the Colle-Salvetti correlation - energy formula into a functional of the electron density. Phys. Rev. B 1988, 37, 785-789.

35. Dreuw, A.; Head-Gordon, M. Failure of time-dependent density functional theory for long-range charge-transfer excited states: The zincbacteriochlorin-bacteriochlorin and bacteriochlorophyll-spheroidene complexes. J. Am. Chem. Soc. 2004, 126, 4007-4016.

36. Boschloo, G.; Hagfeldt, A. Activation energy of electron transport in dye-sensitized $\mathrm{TiO}_{2}$ solar cells. J. Phys. Chem. B 2005, 109, 12093-12098.

37. Palomares, E.; Clifford, J.N.; Haque, S.A.; Lutz, T.; Durrant, J.R. Control of charge recombination dynamics in dye sensitized solar cells by the use of conformally deposited metal oxide blocking layers. J. Am. Chem. Soc. 2003, 125, 475-482.

38. Jang, S.Y.; Seshadri, V.; Khil, M.S.; Kumar, A.; Marquez, M.; Mather, P.T.; Sotzing, G.A. Welded electrochromic conductive polymer nanofibers by electrostatic spinning. Adv. Mater. 2005, 17, 2177-2180.

39. Matsui, M.; Hashimoto, Y.; Funabiki, K.; Jin, J.; Yoshida, T.; Minoura, H. Application of nearinfrared absorbing heptamethine cyanine dyes as sensitizers for zinc oxide solar cell. Synth. Met. 2005, 148, 147-153.

40. Wang, P.; Zakeeruddin, S.M.; Comte, P.; Charvet, R.; Humphry-Baker, R.; Grätzel, M. Enhance the performance of dye-sensitized solar cells by co-grafting amphiphilic sensitizer and hexadecylmalonic acid on $\mathrm{TiO}_{2}$ nanocrystals. J. Phys. Chem. B 2003, 107, 14336-14341.

(C) 2010 by the authors; license Molecular Diversity Preservation International, Basel, Switzerland. This article is an open-access article distributed under the terms and conditions of the Creative Commons Attribution license (http://creativecommons.org/licenses/by/3.0/). 